\title{
الاستشراق في فكر محمد أركون \\ بين الشعور بالمديونية والرغبة في التجاوز
}

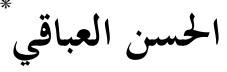

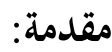

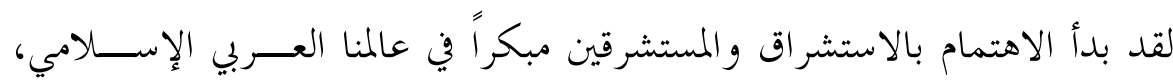

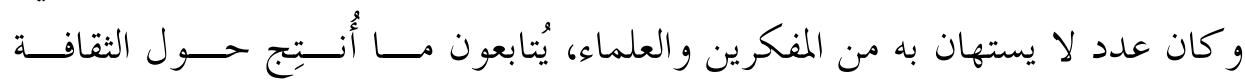

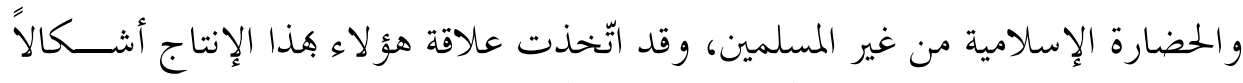

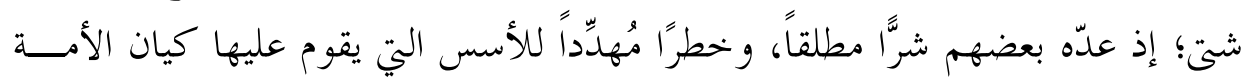

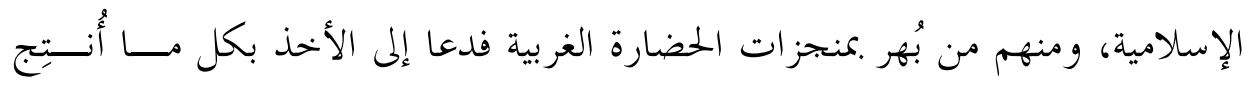

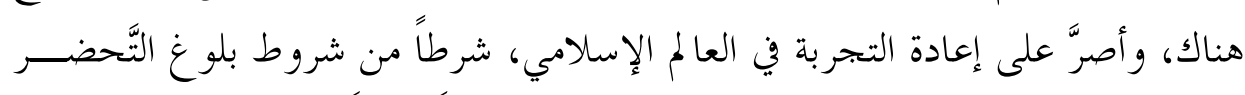

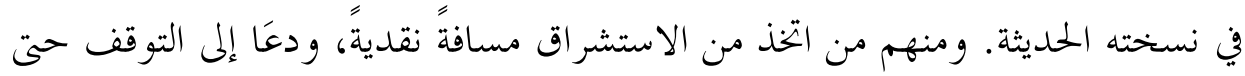

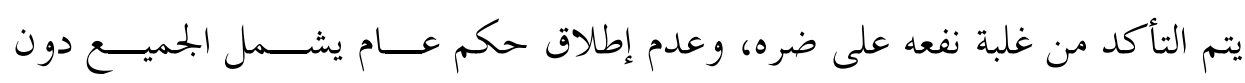

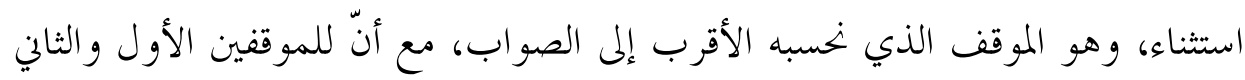

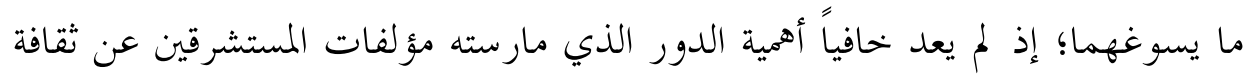

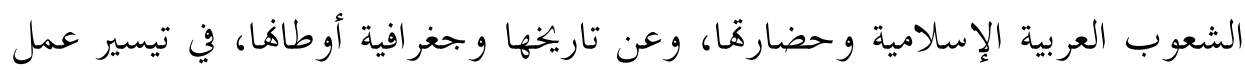

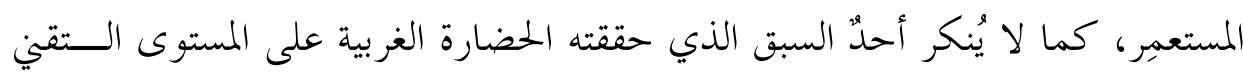

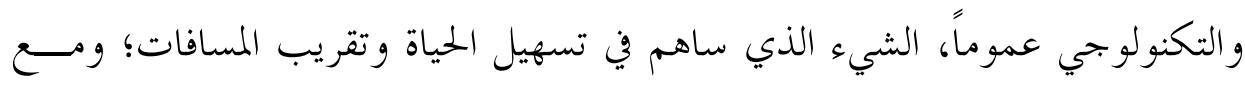
ذلك فهذان الأمر ان لا يعطيان المشروعية برأينا للموقفين الأولين المشار إليهما أعلاه.

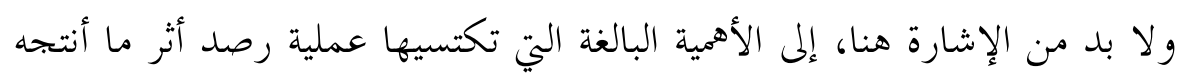

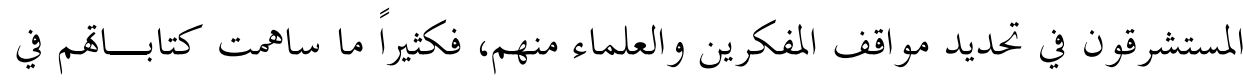
"د كتوراه في وحدة التكوين والبحث: "المناظرات الدينية في الفكر الإسلامي"، الكاتب العام لمععية الإمام ابــن حزم للباحثين في مقارنة الأديان. abbakiha@ @otmail.com 
الدعوة إلى القطيعة معهم، خاصة ما تعلق منها بالعلوم الشرعية، من: قرآن، وحديث،

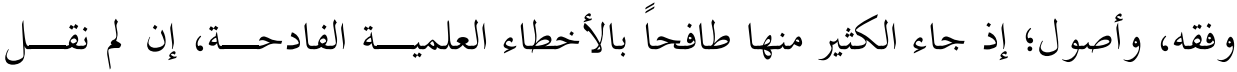
بالتحامل وإطلاق الأحكام غير المؤسسة علميا، وأحسب أن عملية الرصد هذه جديرة بالدراسة والتحليل، وإن كان الاهتمام بها لم يرقَ بعدُ إلى الدرجة التي تستحقها؛ إذ إن

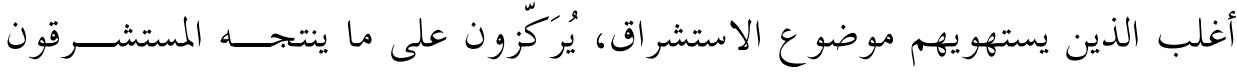
دراسة وتحليلا، غير آهين في كثير من الأحيان برصد أثر هذا الإنتاج في المفكر العـــربي

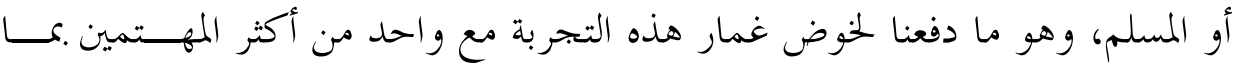
يُكتب عن الإسلام في الغرب، ألا وهو محمد أركون، الذي يدعو إلى إعلى إعادة الاعتبــار

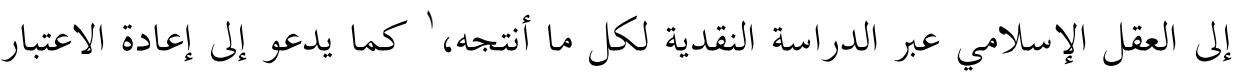

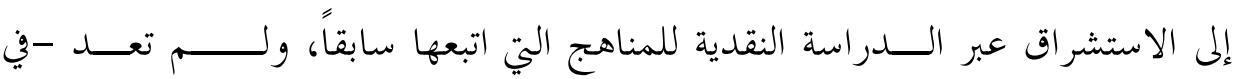

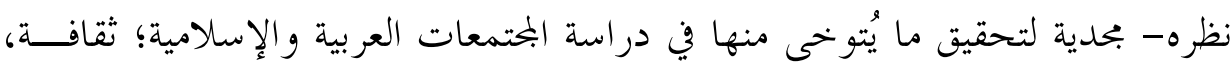
و حضارة، و تاريخاً.

إن المتتبع لكتابات أركون حول الاستشراق والمستشرقين قد يميز مواقف عـــدة، تتأرجح بين الإشادة التي يعزّ نظيرها، مع الشعور بالمديونية من جهة، و المؤاخذة الــيت

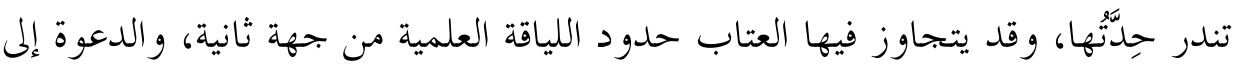
القطيعة مع المناهج المعتمدة في دراسة التراث العربي والإسلامي مع التمسك بالنتـــائج المستخلصة من تلك الدراسات، واستثمارها فيما يقدم من أبحاث من جهة ثالثة؛ وهو ما يوحي بوجود بعض التعارض و التناقض في البناء الداخلي لفكره من هذه الزاويــة،

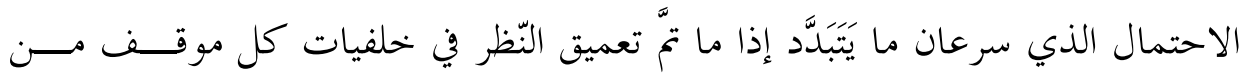
المو اقف الثلاثة أعلاه، مما سيمكننا من تقديم إحدى أعقد صور التعامل مع الاستشر اق؛

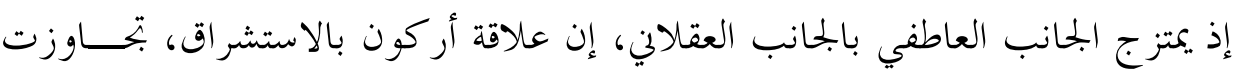

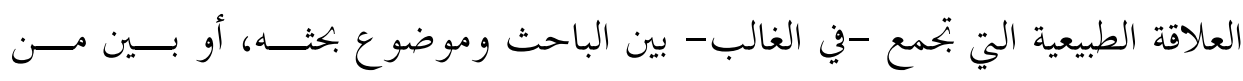

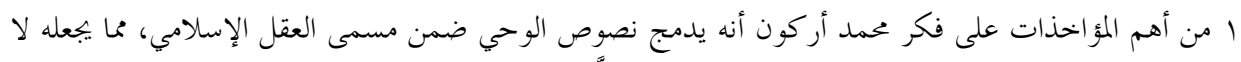

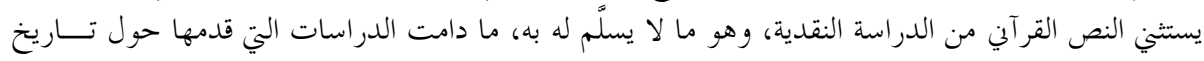

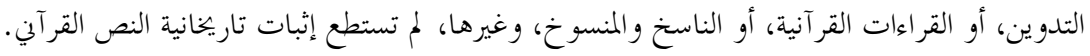




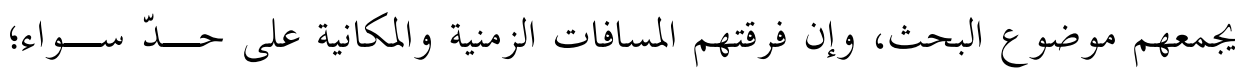

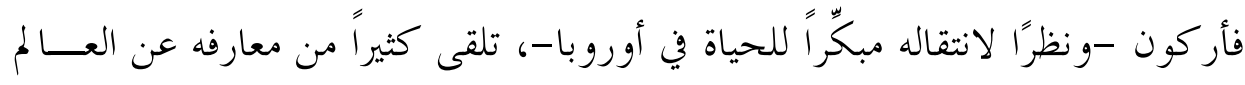

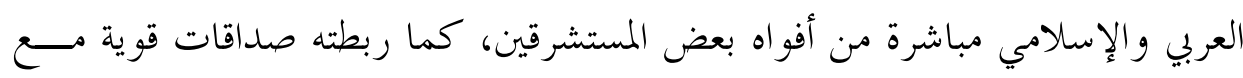

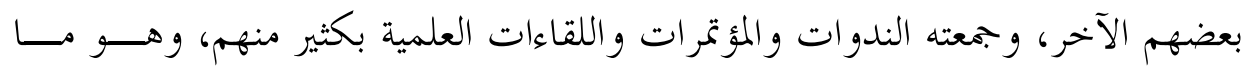

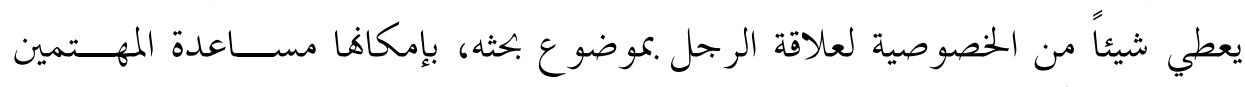
بفكره عموماً على فهم مدى التأثير والتأثر الذي تركه كل طرف فئ في الآخر. لن يكون رصدنا لعلاقة محمد أركون بالاستشراق رصداً وصفياً، بقدر ما سيكون دراسة نقدية للمستويات الثلاثة لتلك العلاقة، هدف من خلالها الانــــــاج في مســــار

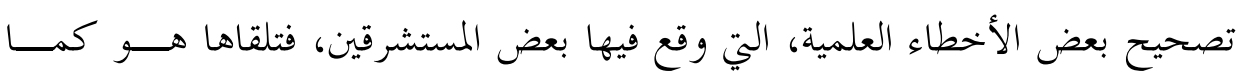

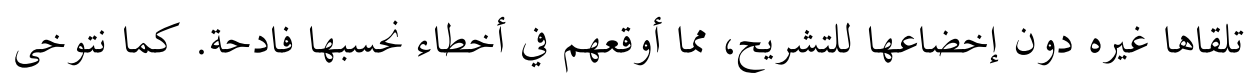

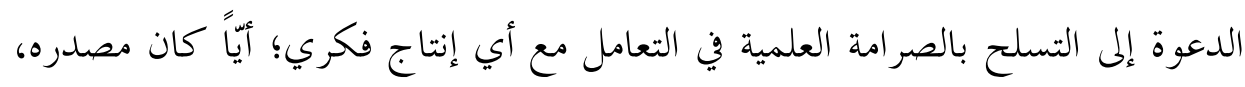

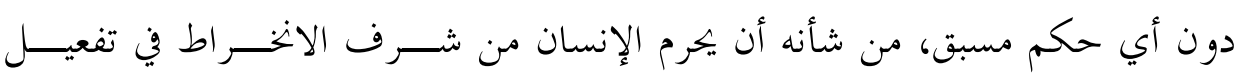

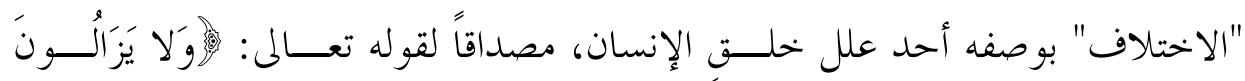

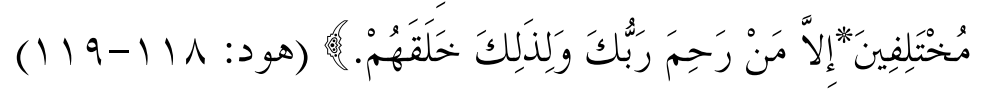

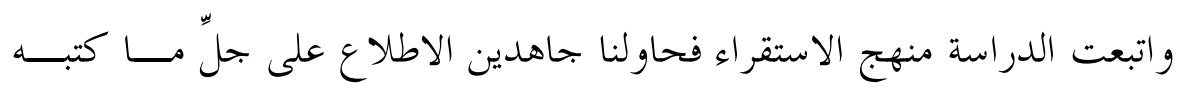

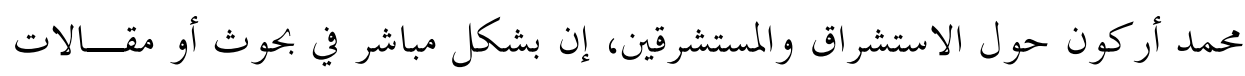
خاصة مفردة لذلك الغرض، أو بشكل عابر ضمن مواضيع مختلفة، ومن ثم شـــرعنا في دراسة تلك الأقوال التي لم يكن بالإمكان إدراجها جميعها هنا، لسبب أساسيّ هو أها

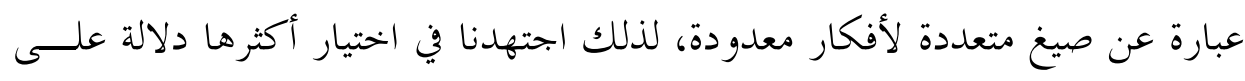

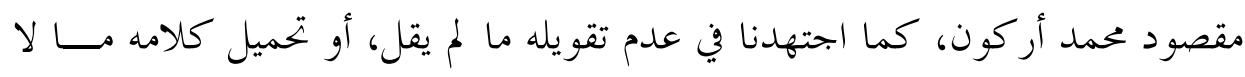
يحتمل. فإلى أي مدى يمكن الحديث عن شعور أركون بالمديونية لما أنتجه رواد الفكر بهر الاستشر اقي؟ وما خلفية عتابه للمستشرقين و شكواه منهم؟ و أين تتجلى دعوته لتجاوز الفكر الاستشراقي؟ هذا ما سنحاول مقاربته في ثلاثة محاور أساسية هي: 


$$
\text { أو لا: مديونية أركون للفكر الاستشراقي }
$$

ثانيا: أركون و الاستشراق - قراءة في خلفية العتاب ودواعي الشكوى

$$
\text { ثالثا: من الإسلاميات الكلاسيكية إلى الإسلاميات التطبيقية }
$$

\section{أولا: مديونية أركون للفكر الاستشر اقي}

لم يكن المستشرقون على قلب رجل واحد، فكما وُجدد من بينهم من قدم للتراث

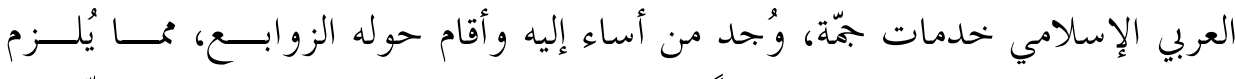

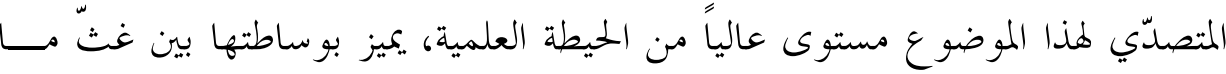

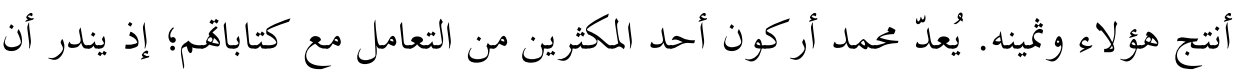

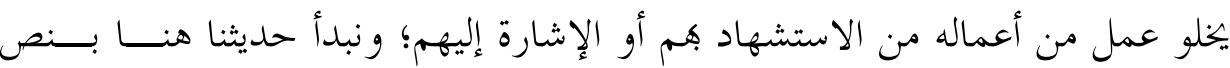

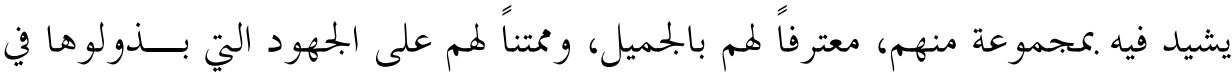

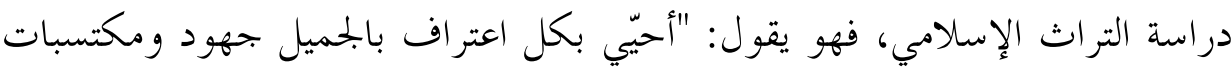

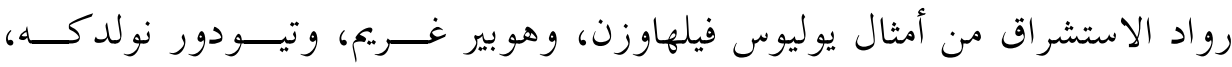

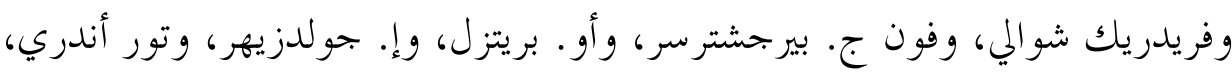

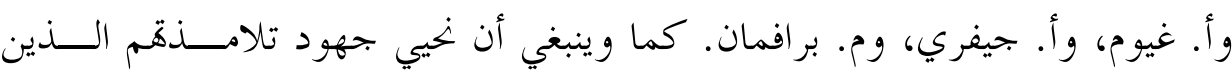

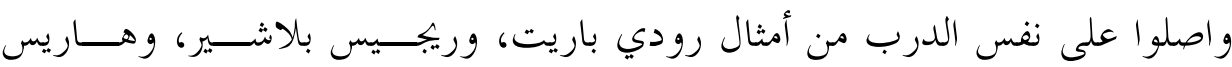

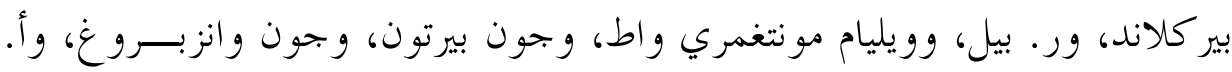

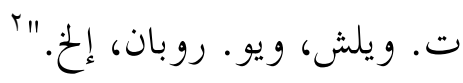
غريب أن يذكر أركون أسماء هؤلاء المستشرقين، ويعترف لهــــــالجميـل دون

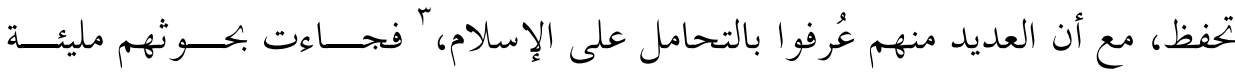

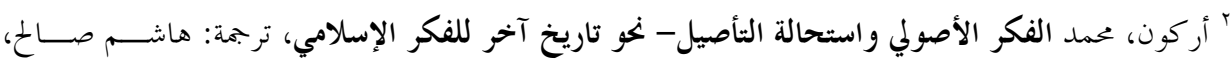

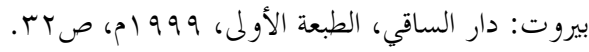

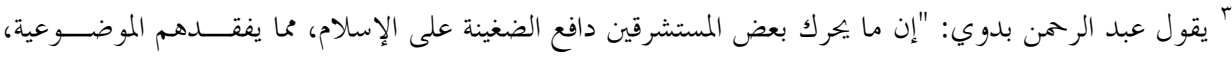

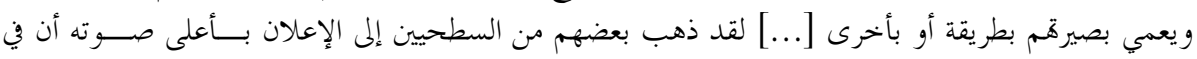




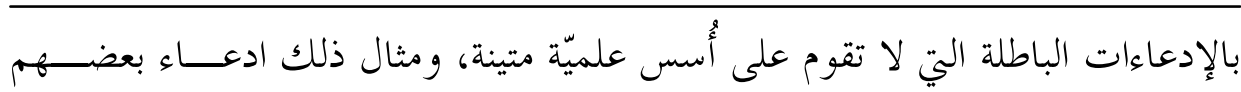

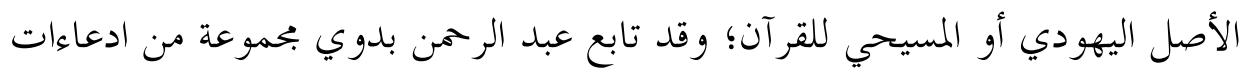

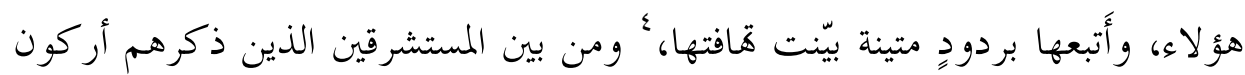

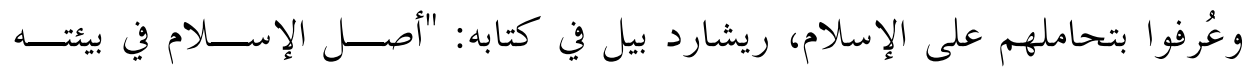
المسيحية"، و تور أندريه Tor Andrae في كتابه: "الإسلام و المسيحية"؛ ويمكن القــــول بأن أغلب الذين ذكرهم لم ينج من التحامل على التراث الإسلامي، و إن كان لبعضهم بحوث قيمة خلطوا فيها بين التدقيق العلمي المطلوب، و الدعاوى المحردة عن الدليل، مما يُلزم المتعامل معها عدم التسليم بأي منها، إلا إذا استند إلى أدلة قوية وبر اهين ولمين متينة. إن أركون يرفض مثل هذا الموقف في قوله: "حتّامَ يستطيع المسلمون أن يستمروا

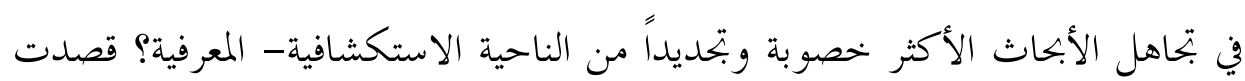

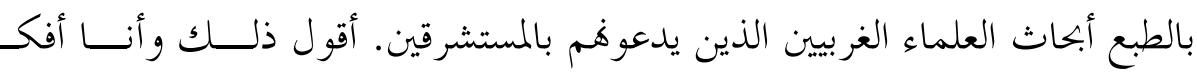

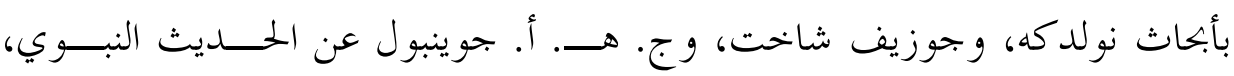

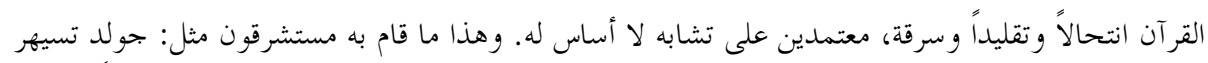
Goldziher

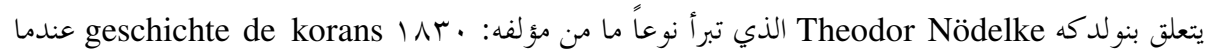

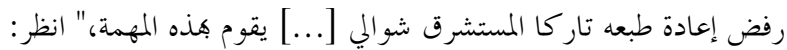

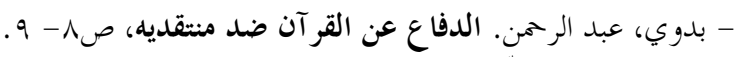

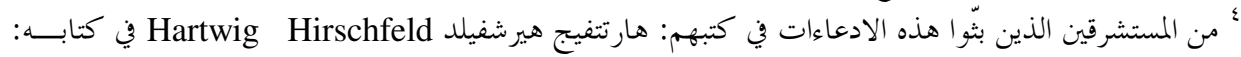

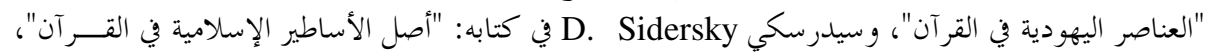

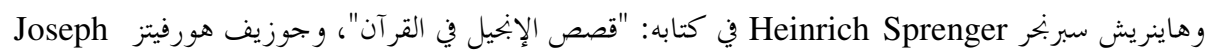
Horoivitz

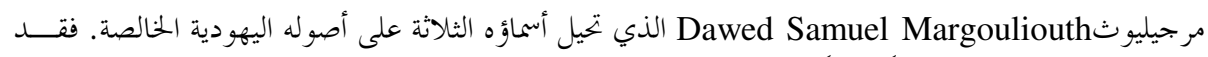

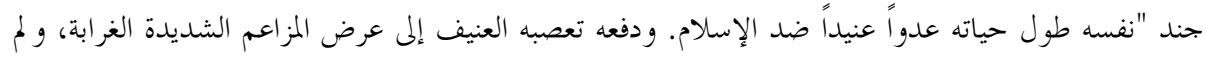

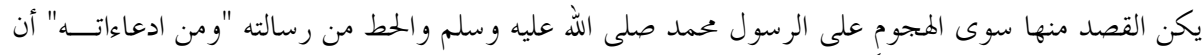

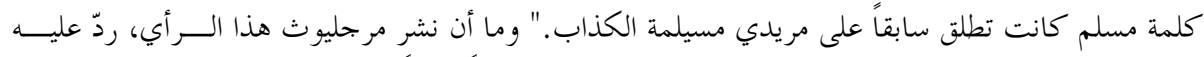

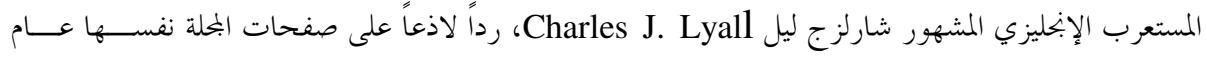

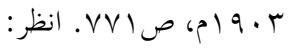

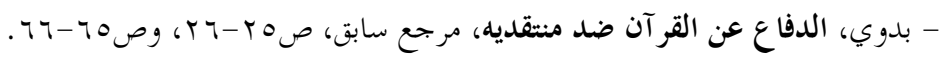




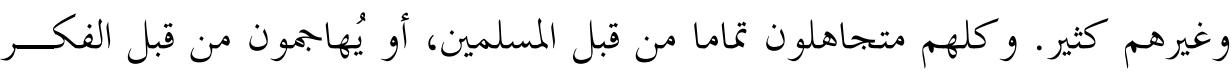

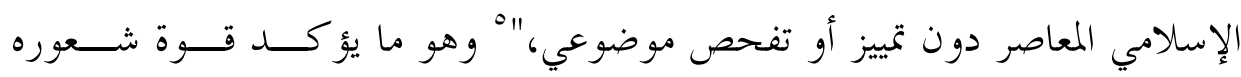

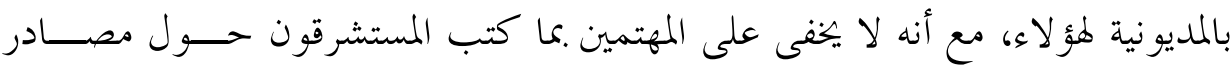

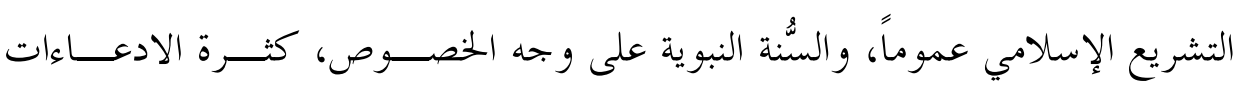

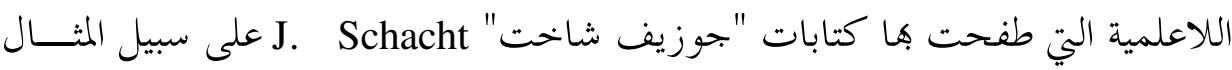

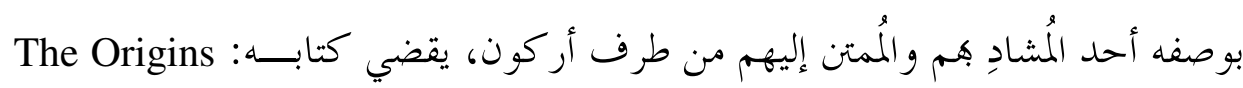
of Muhammadan Jurisprudence

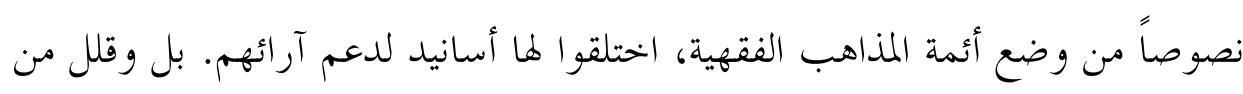

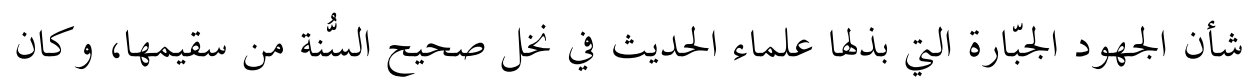

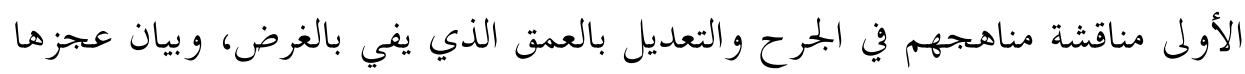

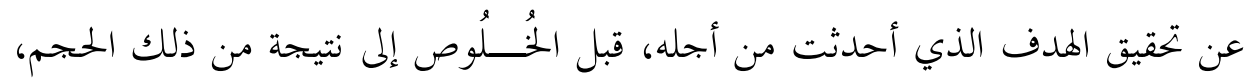

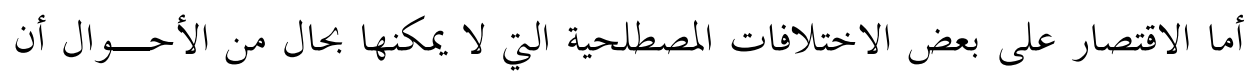

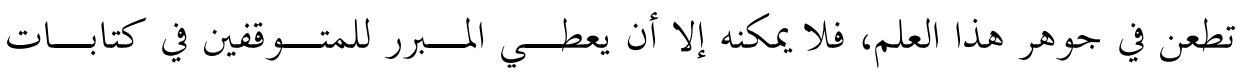

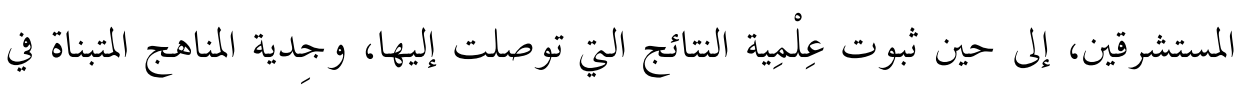
ذلك.

إن الإشادة بكل أولئك المستشرقين، دون أدلن تحفظ، فيه الكثير من المحازفة الــتي

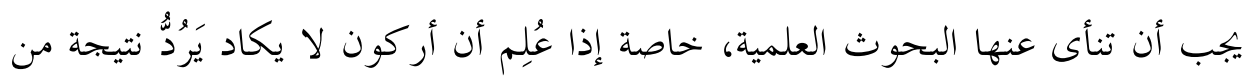
نتائج رو ادهم الذين يشعر بالامتنان لهم والمديونية لما كتبوا، ومنها حديثهم عن الترتيب

ه أركون، حمد. قضايا في نقد العقل الديني- كيف نفهم الإسلام اليومج ترجمة: هاشم صـاح، بـيروت: دار

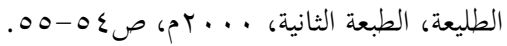

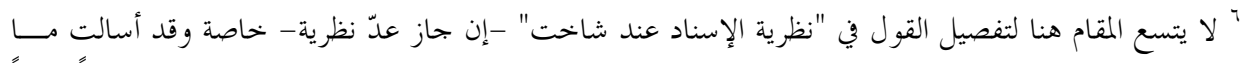

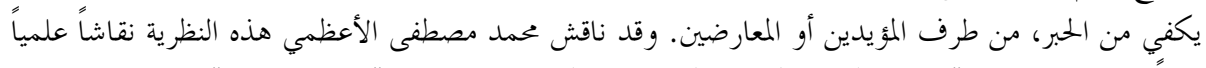

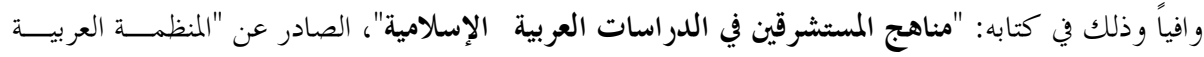

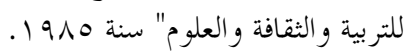


الزمين (الكرونولوجي) لسور القرآن بحسب تاريخ نزوها؛ إذ جاء كلامه في هذا المقام

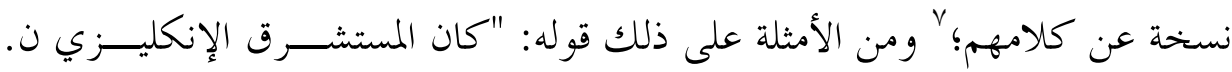

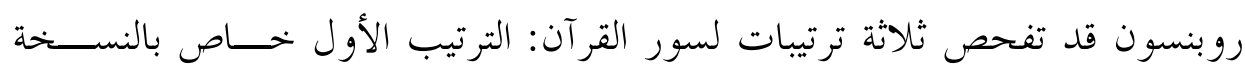

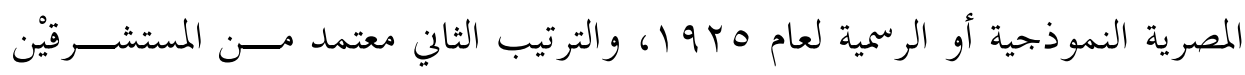

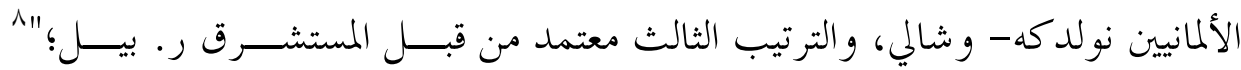

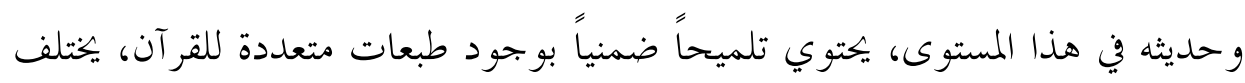

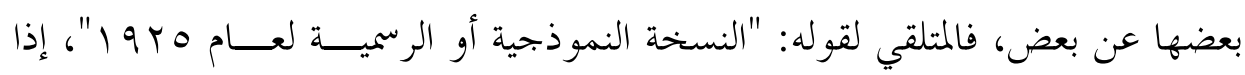
كان قليل الزّاد في هذا المحال، قد يظنّ أن هناك طبعة مصرية غير رسمية للسنة نفســـــها، وربما طبعتين رسمية وغير رسمية للسنة الموالية، وهكذا؛ كما يشمل القـــول احتمــــال

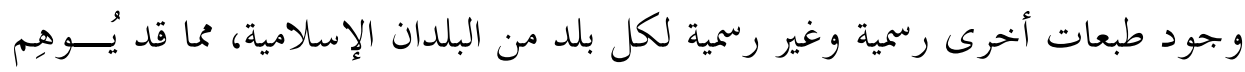

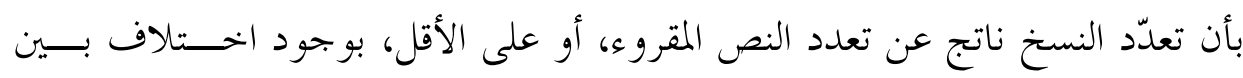

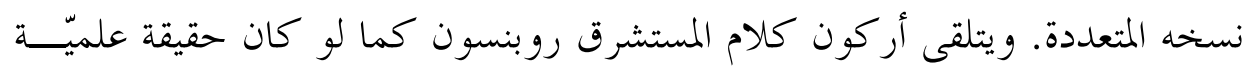

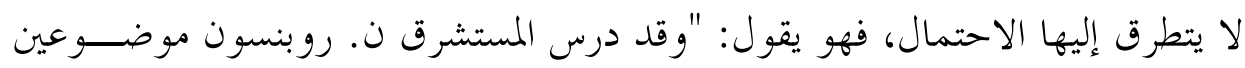

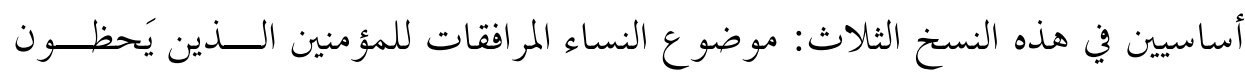

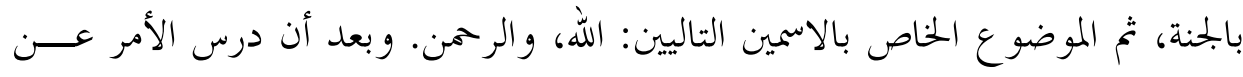

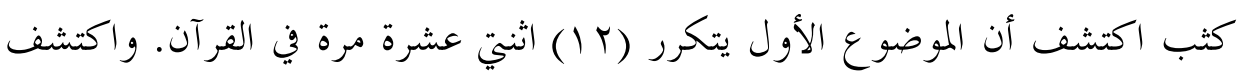

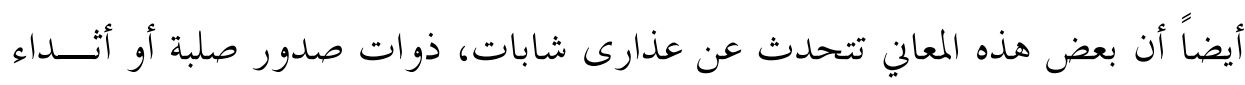

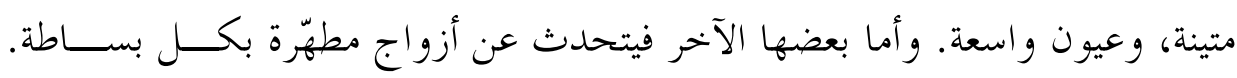

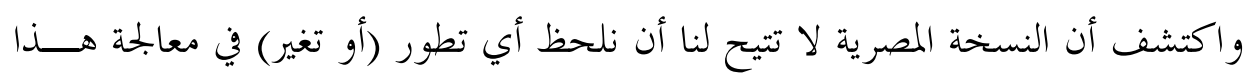

ل من ذلك قوله: "إن احترام التسلسل الزمني (أو الكرونولوجي) للآيات القرآنية (أو للعبارات النصية القرآنية) يتيح

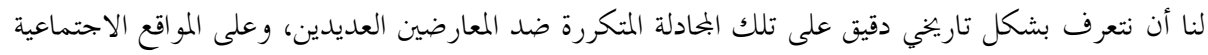

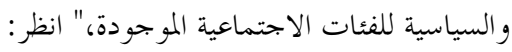

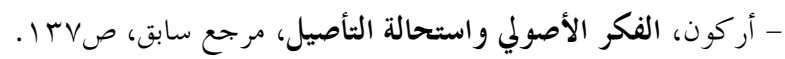

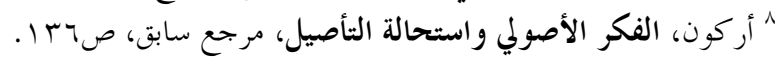


الموضوع على مدار القرآن كله. وأما نسخة نولدكه-شالي و ر. بيل فتكشف عن أن

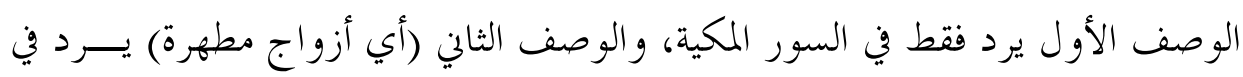

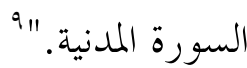

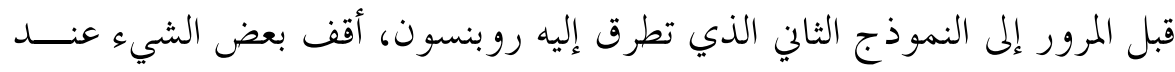

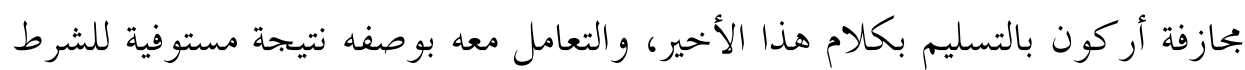

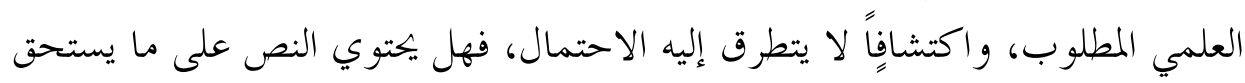

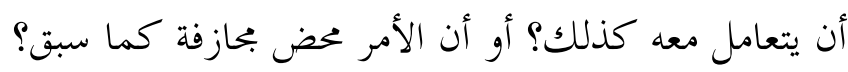

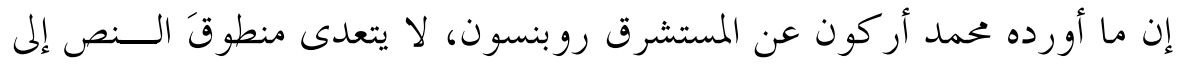

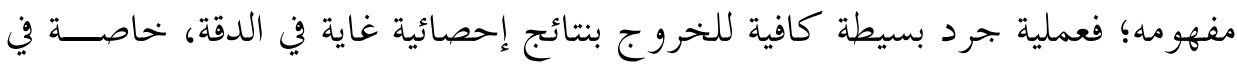

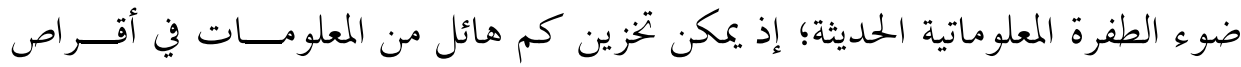

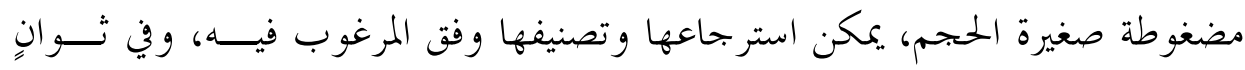

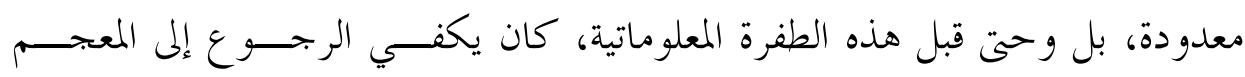

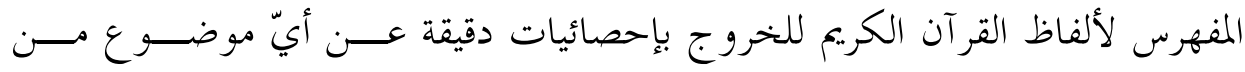

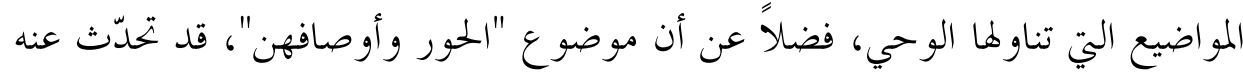

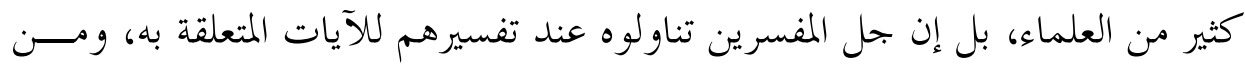

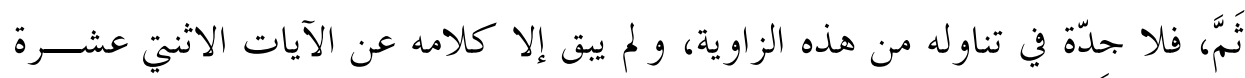

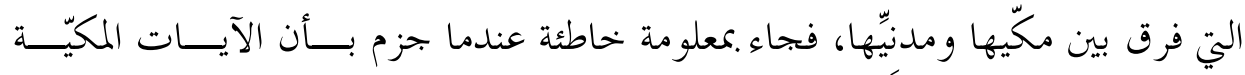

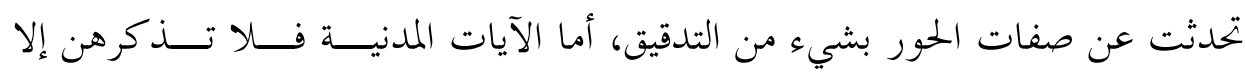

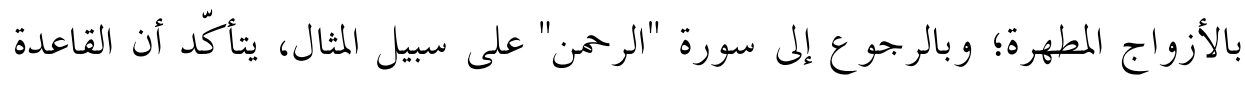

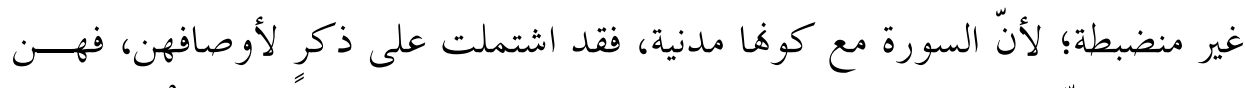

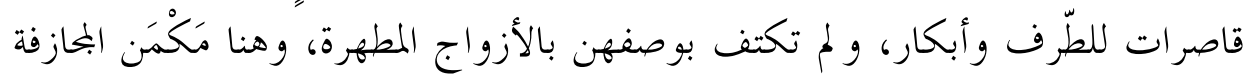

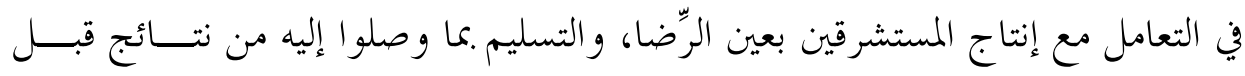
تمحيصها. 


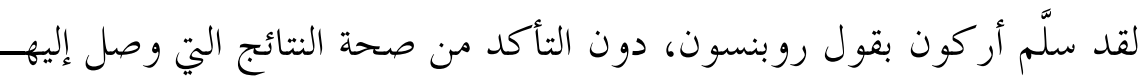

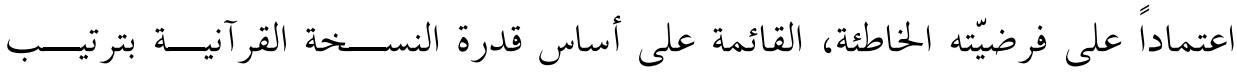

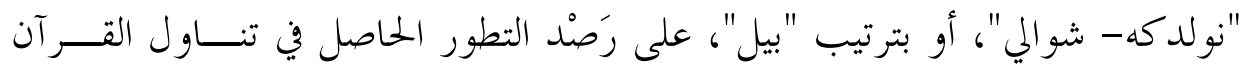

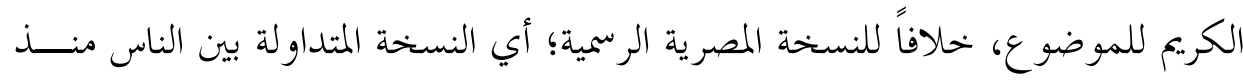

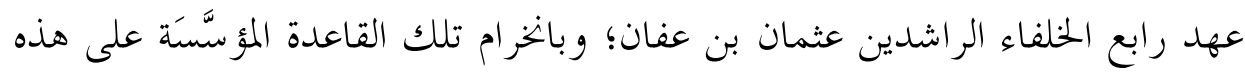

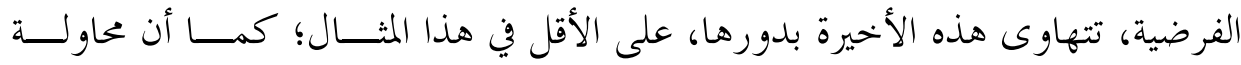

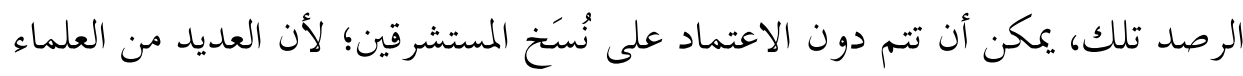

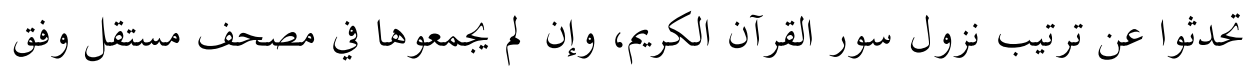

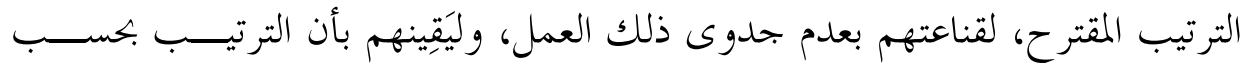

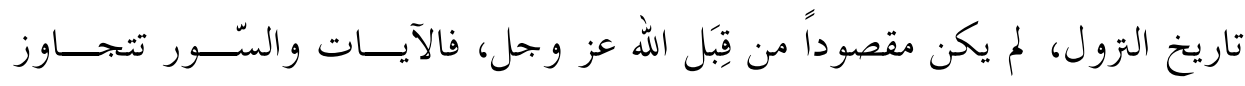

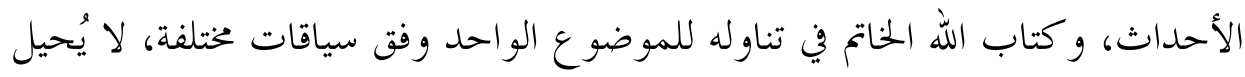

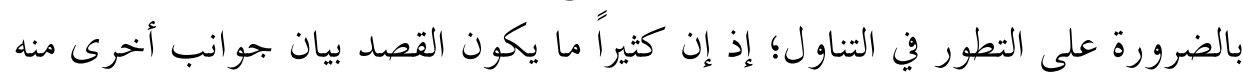

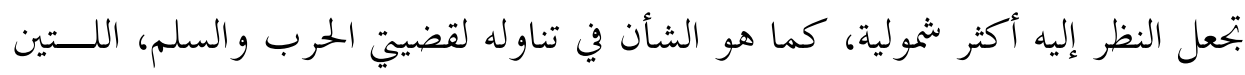

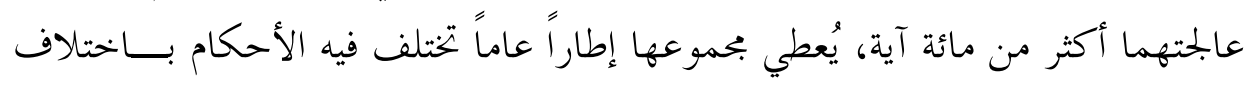
الظروف والحيثيات.

أما النموذج الثاني الذي أشاد به محمد أركون، فيتعلق بكلام روبنسون عن كلمتي

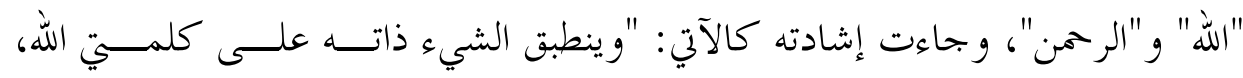

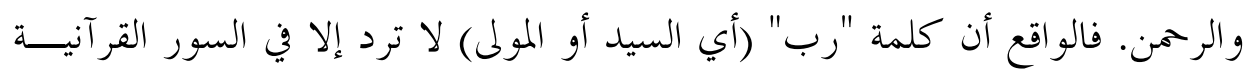

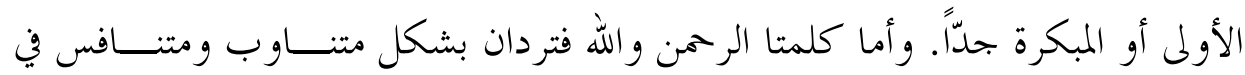

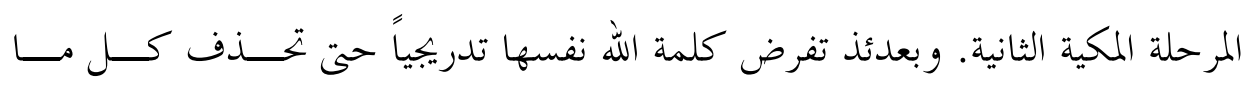

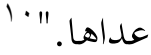

وإذا عُلمِم بأن المرحلة المكية الثانية عند نولدكه وشوالي، تبدأ بسـورة الكهـــف

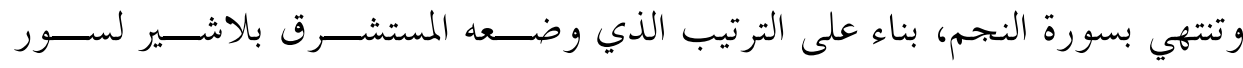


المصحف، وذلك في كتابه: "القرآن: نزوله، تدوينه، ترجمته و تأثيره،" "' فَسَيُسنــتخلص

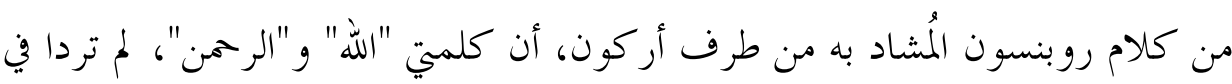
المرحلة المكية الأولى؛ لأفما لم تظهرا إلا في المرحلة الثّانية، لكن بالرجوع عُ إلى الســور

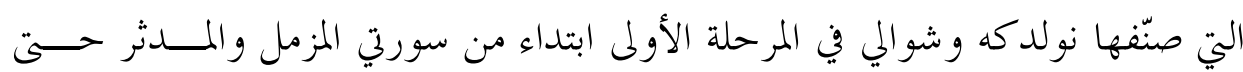

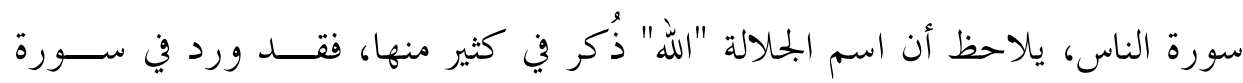

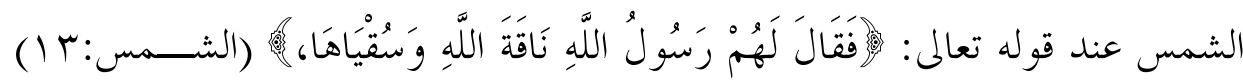
وهي السابعة في ترتيب التزول حسب نولدكه-شوالي، كما ورد في سورة الأعلى عند

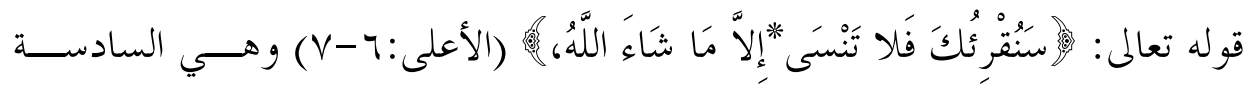

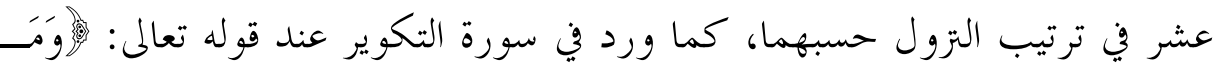

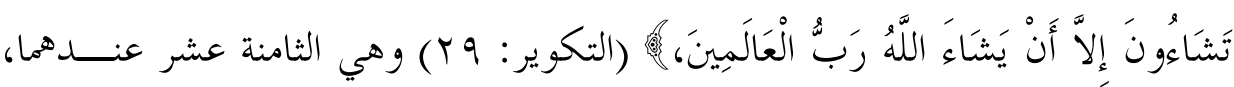
وقد ورد أيضا في سورة الانشقاق التي جعلاها بعد سورة التكوير في ترتيب الترول في

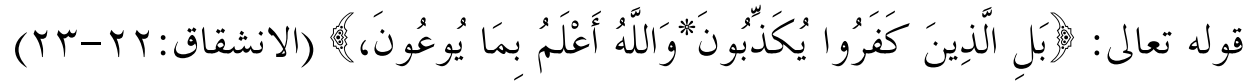
أما كلمة "الرحمن" فقد وردت مرّتين في سورة النبا وهي السادســـة والعشـــرون في ترتيب التزول حسب نولد كه-شوالي.

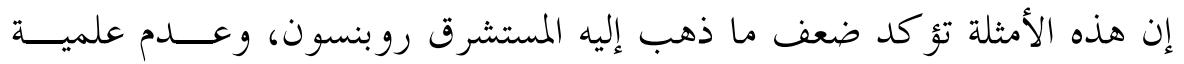
النتائج التي بناها على تلك الاكتشافات. أما كلمة "رب" التي قال بأها لم تـــرد إلا في السور القرآنية الأولى أو المبكرة، فالخطأ فيها أفحش؛ إذ ذُكرت في السّور المدنية بصيغ مختلفة أكثر من مائيت مرة، تسع وأربعون منها في سورة البقرة وحدها، و ثمانٍ وثلاثون في سورة آل عمران، وست مرات في سورة النساء، وسبع عشرة مرة في سورة المائدة، وست وثلاثون مرة في سورة الرحمن، إلخ.

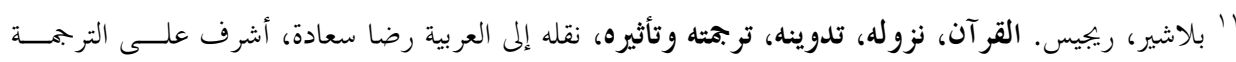

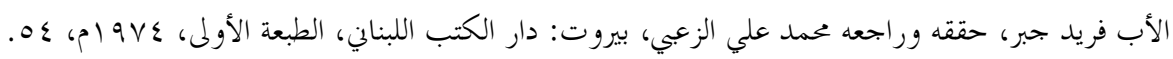




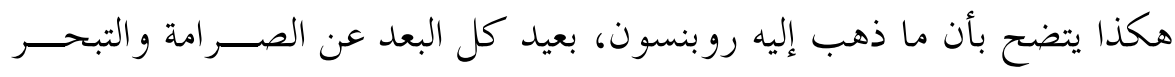

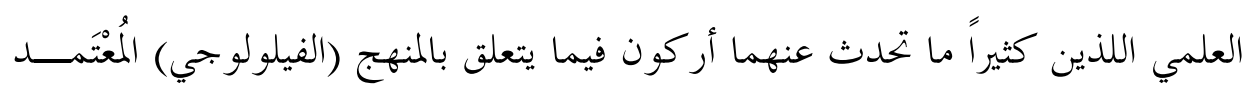
من قبل المستشرقين. ويبدو أن تلك الأمثلة، تنمّ عن قلة زاد المستشرق روبنسون بالمادة

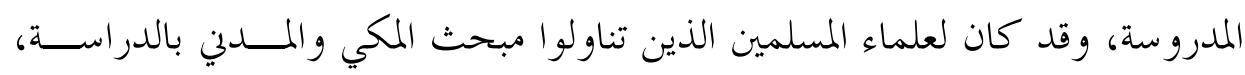
كالام أدق بكثير مما ذهب إليه هذا الأخير، ليس هذا مقام التفصيل فيــه. إن شــعور

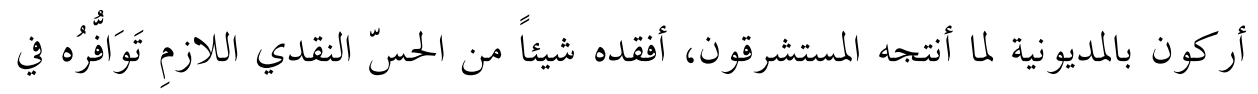
البحوث العلمية، و جعلته يقبل نتائج بحوثهم دون إخضاعها للدراسة النقدية. وهناك تمظهر آخر لذلك الشعور بالمديونية، يتعلق بإشادته المبالغ فيها -في كـثـير

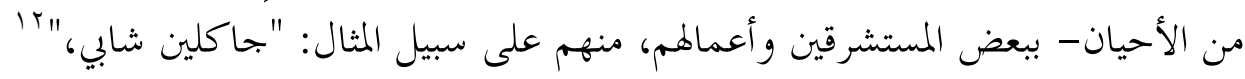

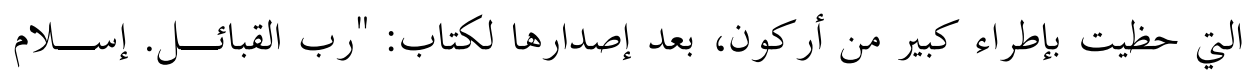

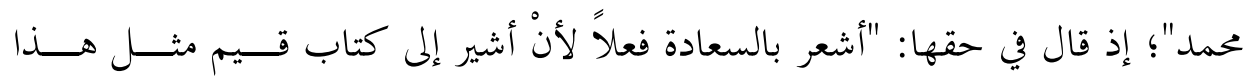

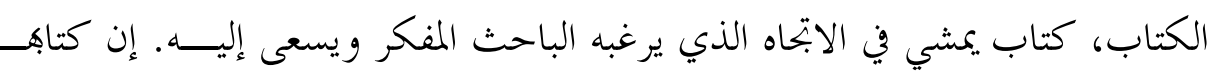

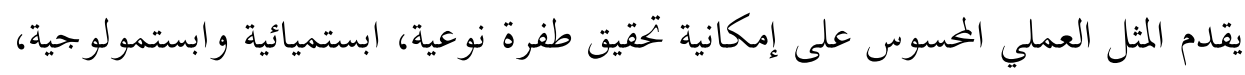

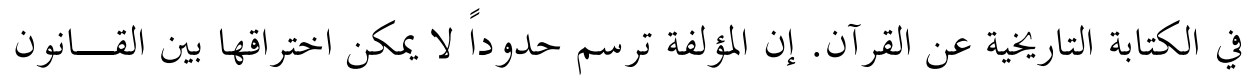

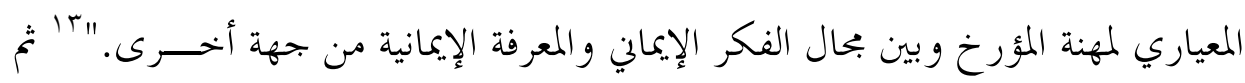

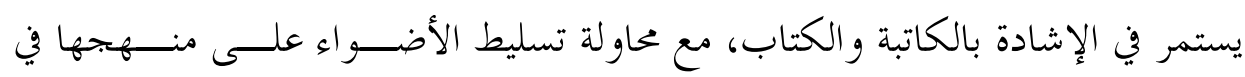

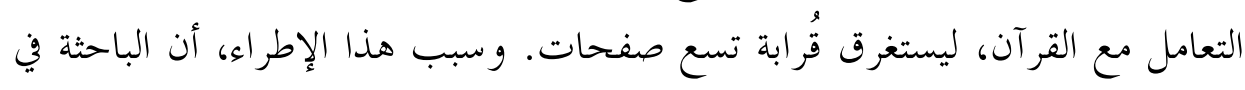

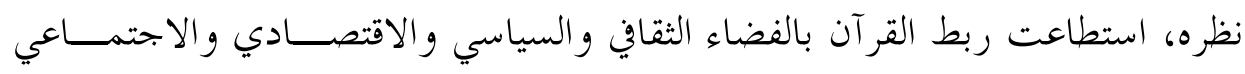

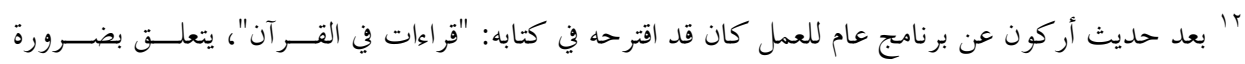

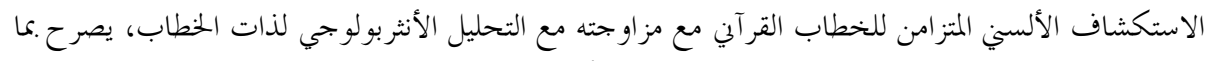

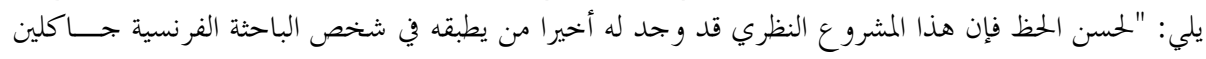

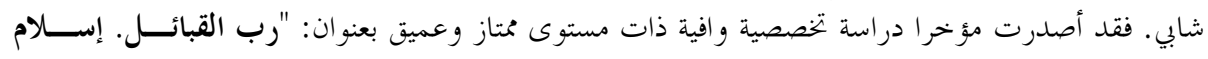

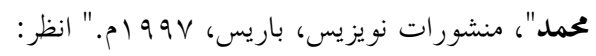

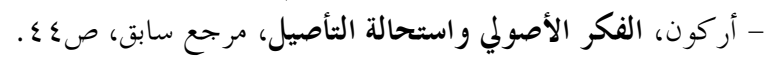

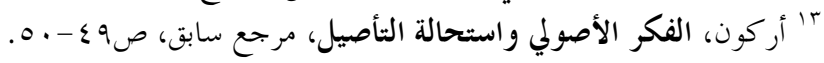




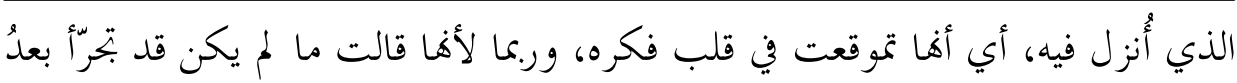
على قوله بكل تلك التفاصيل؛ '.

\section{ثانياً: أركون والاستشراق - قراءة في خلفية المعاتبة ودواعي التشكي}

كثيرة هي عبارات العتاب الحاضرة في كتابات أركون، لا ســيما في مقـــدمات

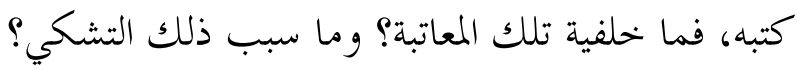

تحدثت في النقطة السابقة عن وجه بارز في علاقة أركون بالاستشراق، يتجلى في

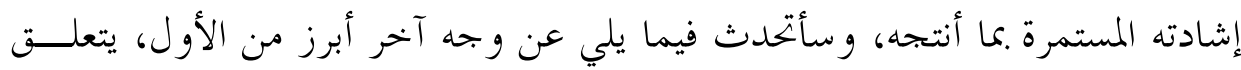

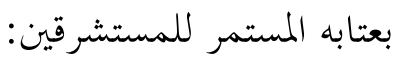

أ. عتابه لكلود كاهين: قال عنه في الدراسة التي خصصهاْ له في كتابه: قضــايا

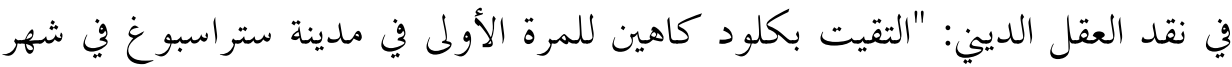

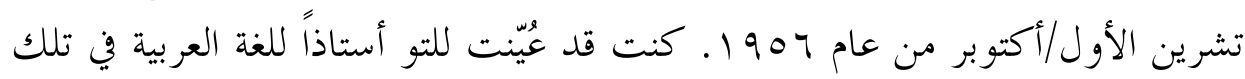

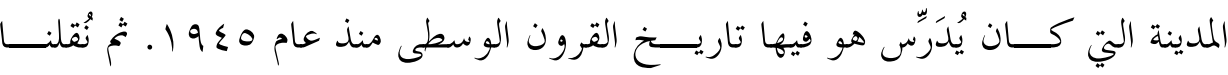

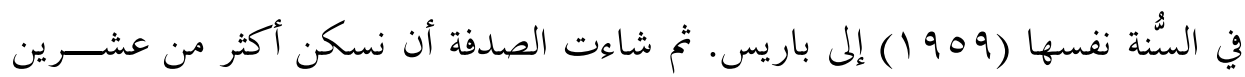

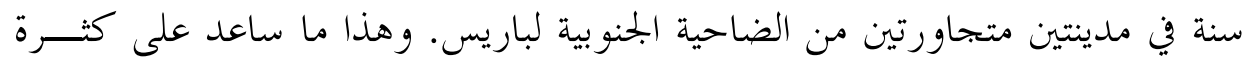

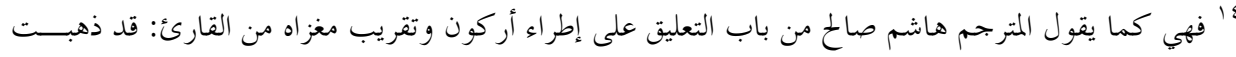

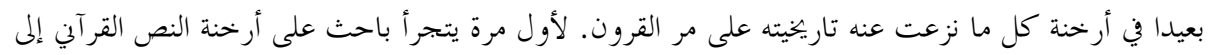

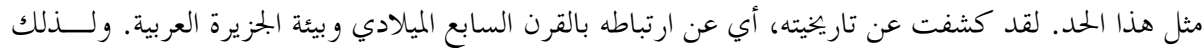

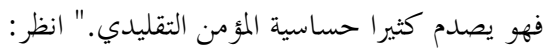

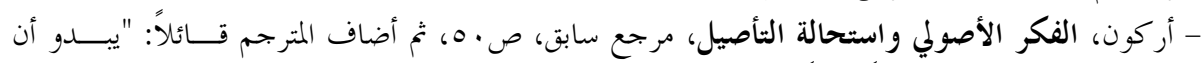

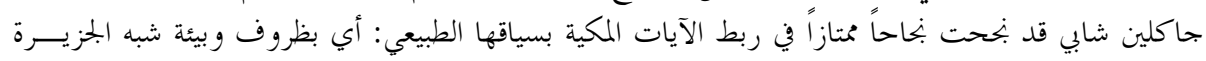

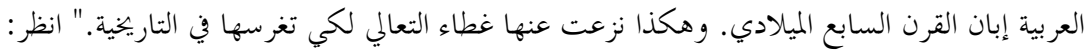

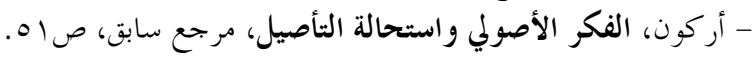

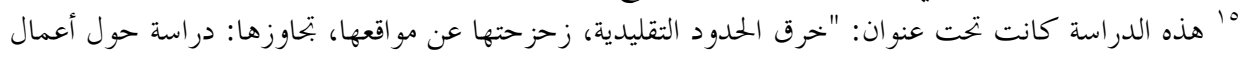

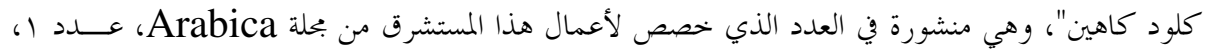

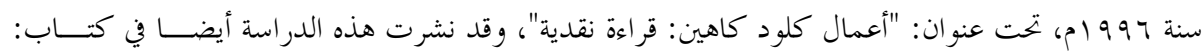
"قضايا في نقد العقل الديني". 
حوار اتنا ومناقشاتنا." "العلاقة بين الرجلين حسب ما يبدو من خلال النص، متينــة

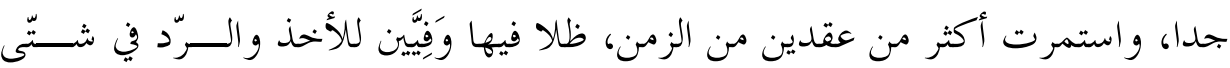
المو اضيع.

وقد لا تبدو الصلة قائمة بين النص المستشهَد به، وقضية العتاب، لكن، إذا عُلـــم

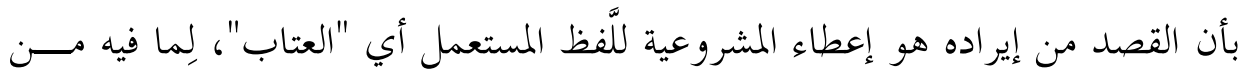

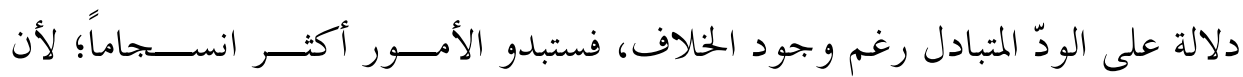

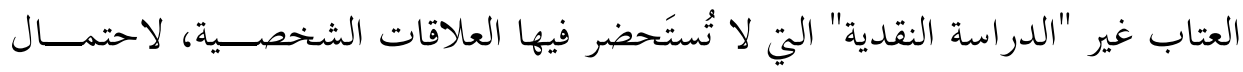
تأثيرها السبي على العلمية والموضوعية؛ فما الذي يؤ اخذه أركون على كاهين؟ يقول في ذلك: "العلماء الأكاديميون الذين يعيشون في الظل (مثل كلود كـــاهين) يستمرون في كتابة التاريخ على الطريقة الوصفية الحيادية الباردة. معتى أهم يكتفــــون بنقل أقوال أو خطابات الفاعلين الاجتماعيين (أي المسلمين هنا) إلى اللغات الأوروبية كالفرنسية والإنكليزية. ولا يقومون بتفكيكها من الداخل، أو محاولة تعريسـة الأبعــاد الأيديولوجية التي تنطوي عليها بالضرورة كأي خطاب بشري." "Vا" ولعله بادٍ للعيان أنّ المؤ اخذة هنا، منصبّة على بجال التقاطع بين نظرته للتراث الإسلامي، ونظـــرة كلـــود كاهين لما، فكأنه يريد دبحه -ومن خلاله كل المستشرقين- في برنامج عمله؛ إذ يُطالبه كما يتجاوز المهمّة الأساسية للمؤرخ، كالبحث عن الأسباب الحقيقيــة الكامنـــة وراء. الأحداث التاريخية، أو الأبعاد الأيديولوجية التي تنطوي عليها، فتلك مهمّة علماء مـــن صنف آخر، تختلف آليات اشتغالهم عن آليات اشتغال المؤرخ. وهذا ما لم ينتبه إليـــ أركون في النص أعلاه، فطالب كاهين كمؤرخ بما هو خارج عن نطاق عمله مؤرخاً،

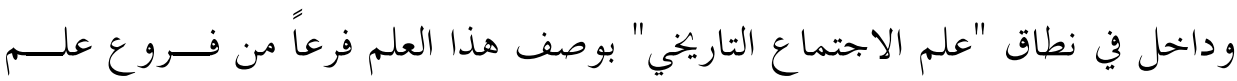




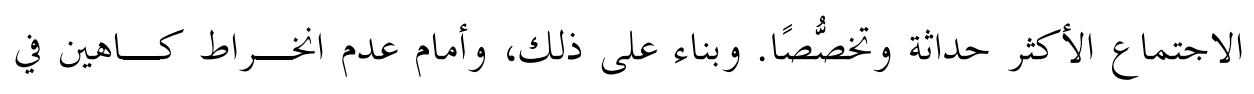

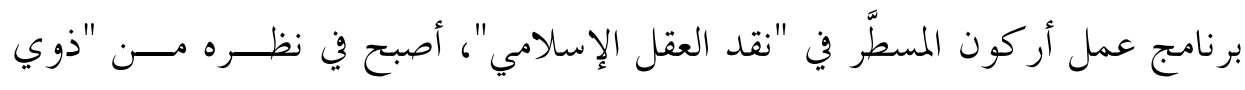

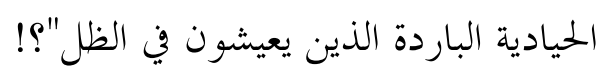

ب. عتابه للمستشرقين المعاصرين: لا يختلف موقف أركون السابق مــن كلــود

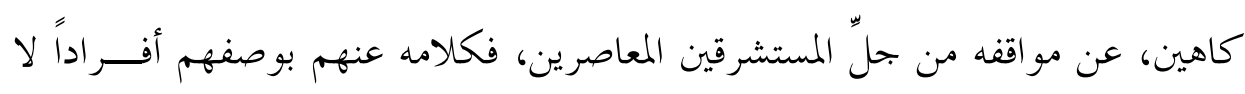

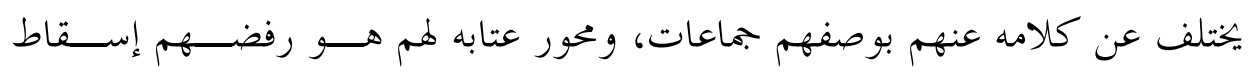

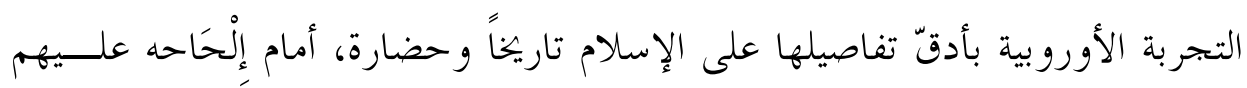

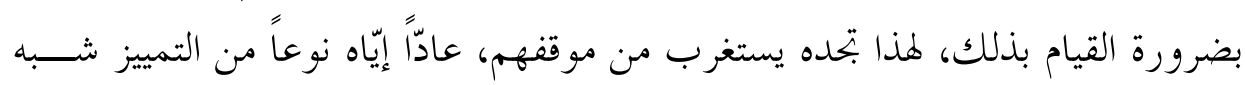

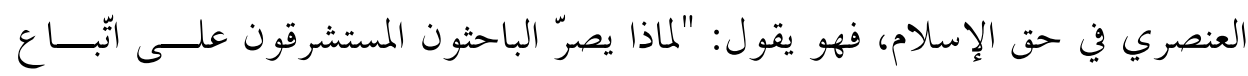

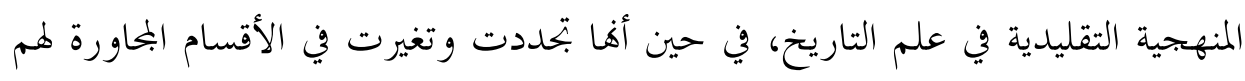

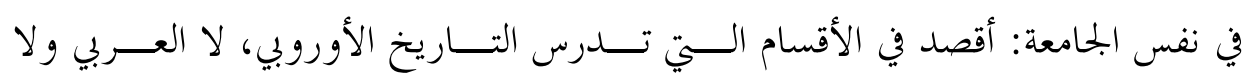

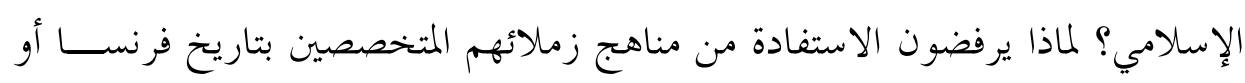

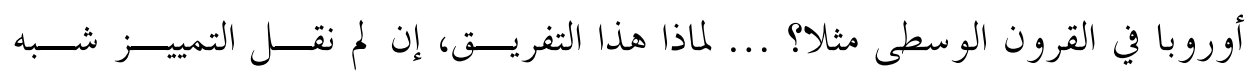

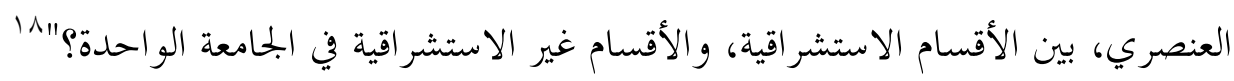

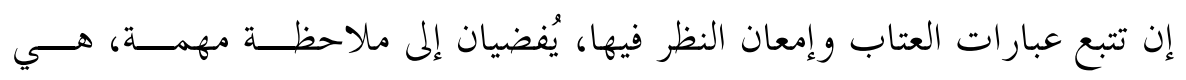

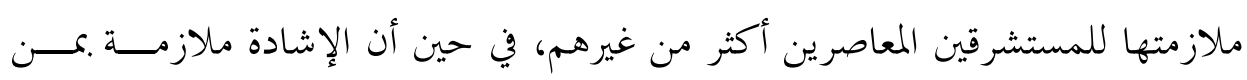

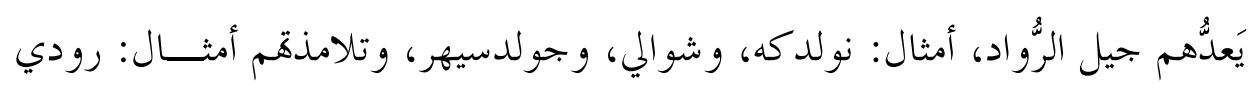

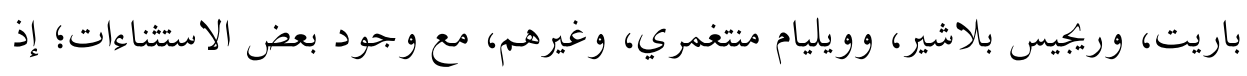

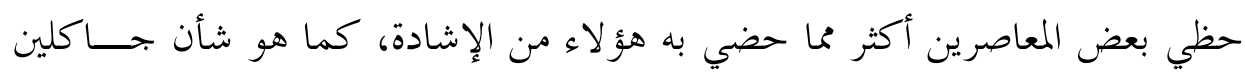


شابي، في حين جمع موقف أركون من المستشرق الألماني جوزيف فــان إيـس، بـــين الإطر اء و العتاب.

إن الخلفية التي تحكم أركون في عتابه للمستشرقين، تكمن أساساً في كون "العلم الاستشراقي كان محصوراً بالتأريخ للوقائع الخام للتراث و استعادها عن طريق استخدام المنهجية الفيلولوجية من نحو وصرف ومعاجم ودراسة تركيب الجمل، إلخ ... و وكــان

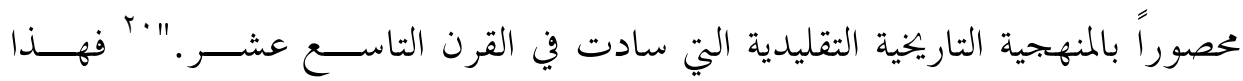

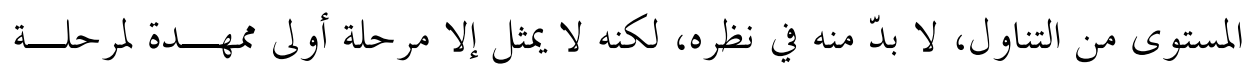

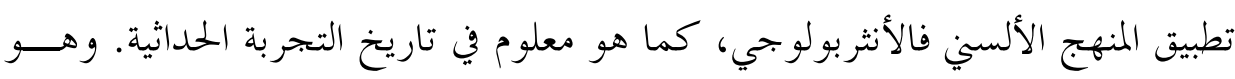
لا يعاتب جيل الرواد؛ لأن المكتشفات الحماثية على المستوى المنهجي لم تكن متو افرة

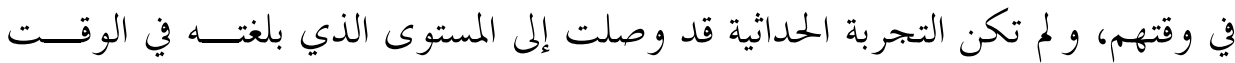

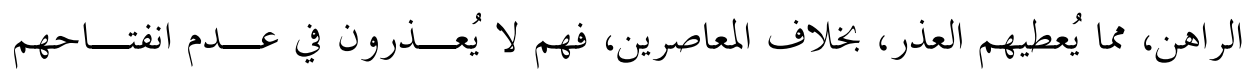
المنهجي عليها.

\section{ثالثاً: من الإسلاميات الكلاسيكية إلى الإسلاميات التطبيقية}

تُعدّ "الإسلاميات التطبيقية" البديل المنهجي الذي اعتمده أركون في "نقد العقــل

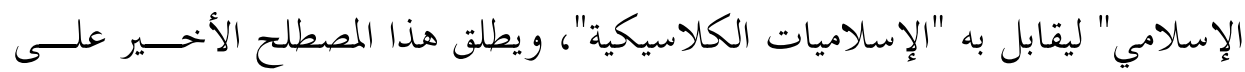

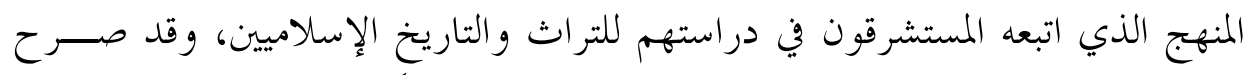

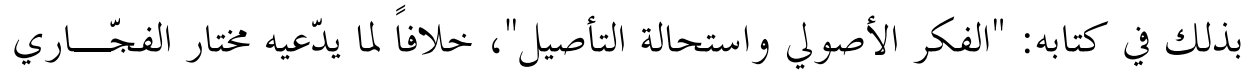

19 رغم اعتزاز أركون بمؤلفات جوزيف فان إيس، وخاصة موسوعته: "اللاهوت والمحتمع في القرنين الثاني و الثالث

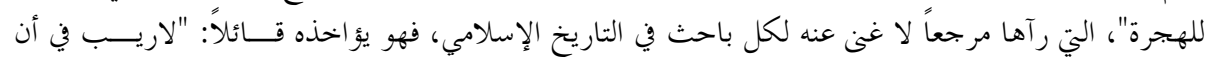

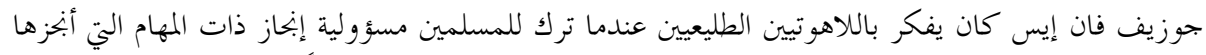

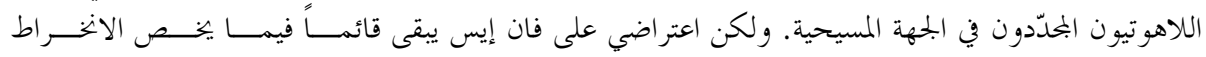

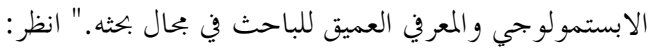

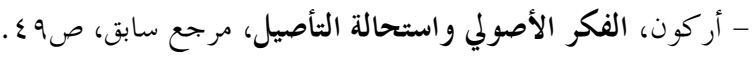

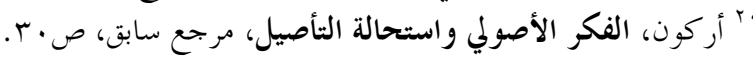




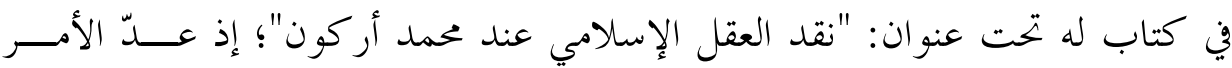

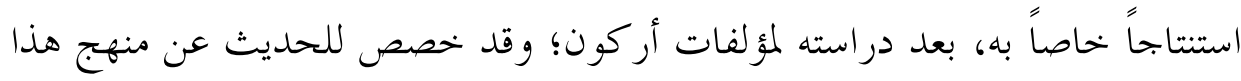

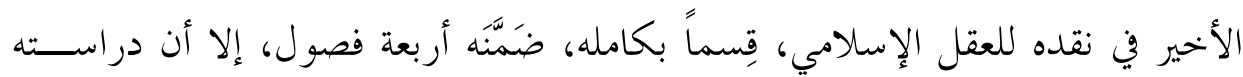

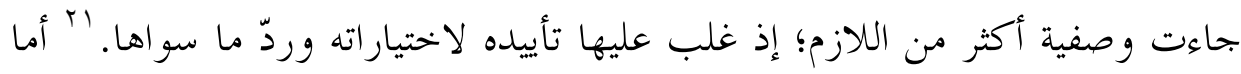

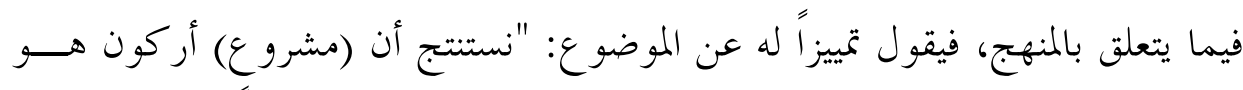

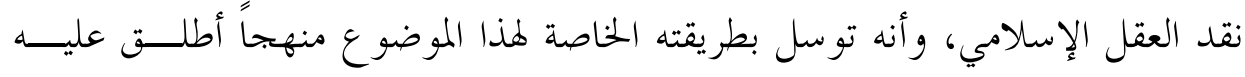

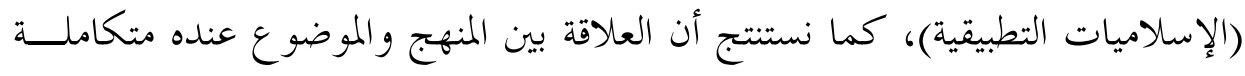

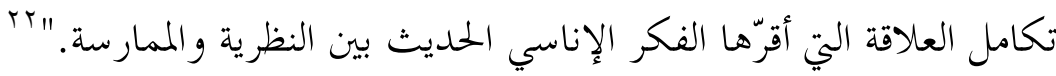

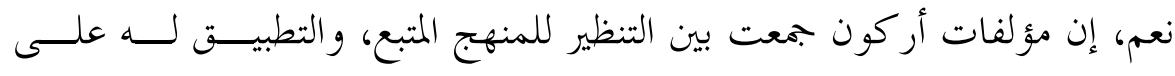

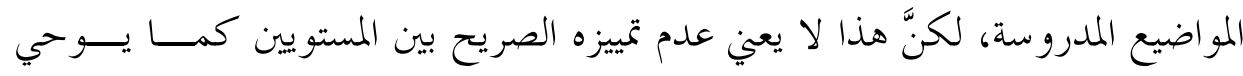

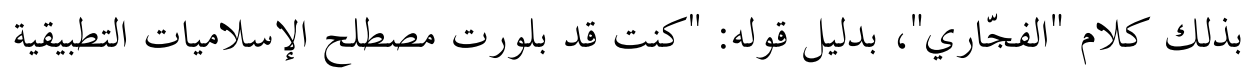

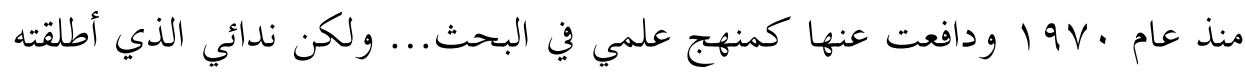

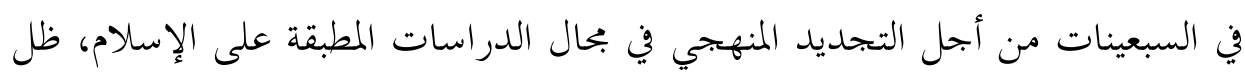

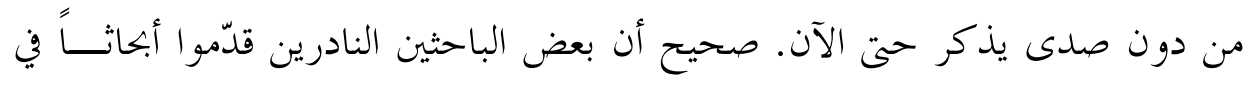

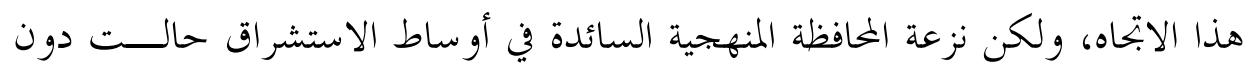

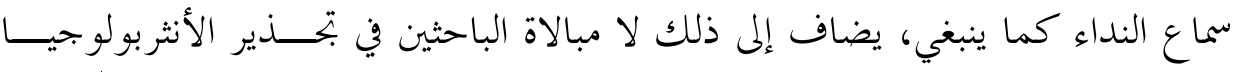

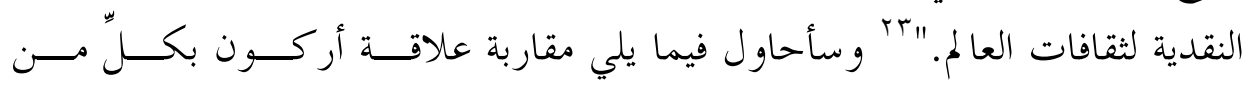
الإسلاميات الكلاسيكية والإسلاميات التطبيقية:

" لا نبالغ إن قلنا بأن عبارات الفجّاري واستنتاجاته تدخل في ما أسماه أركون بالكتابات التبجيلية، وقولـهـ الآتي

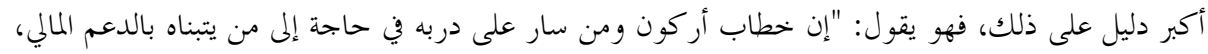

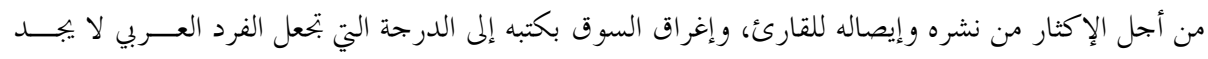

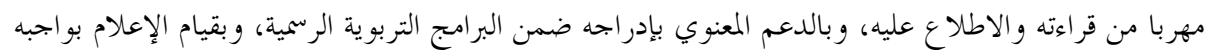

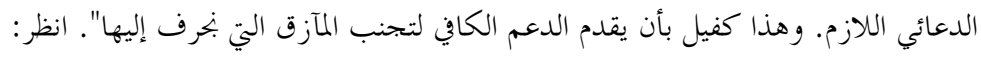

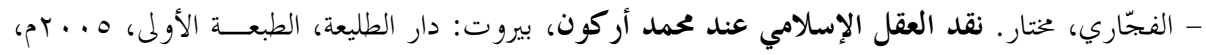

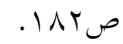

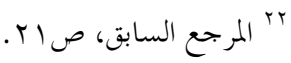

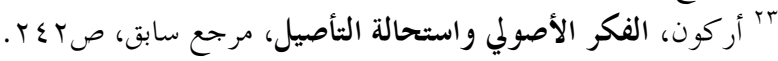


ا ـ إن موقف أركون السلبي من الإسلاميات الكلاسيكية أو التقليدية لا يتعارض

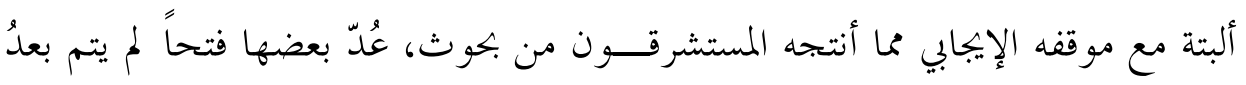

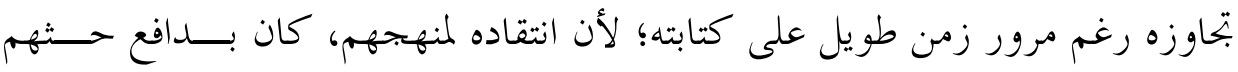
على تبني ما استجد من مناهج، همدف توسيع أفق تناولهم للقضايا التراثية، وهو أمــر جلي” في عتابه لنموذجين بارزين من المعاصرين، هما كلود كاهين وجوزيف فان إيس،

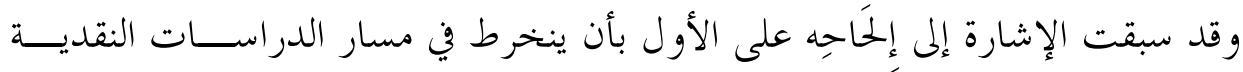
منظورها الحداثي المتجاوز للمنظور الاستشراقي، الذي يكصر نفسه في منهج بال، و لم.

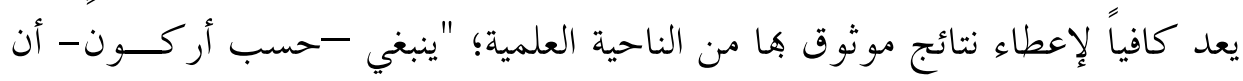

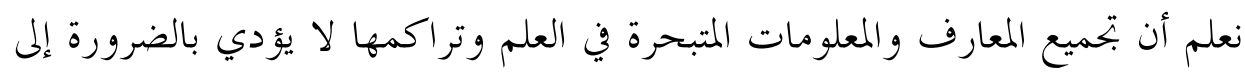
توليد فكر نقدي، أو إبداعي، أو تحريري، بالطبع فإن بتميع هذه المعلومات يشــــل مرحلة لابد منها، أي المرحلة الأولى من الدراسات العلمية. ولكن لا ينبغي الاكتفاء هـا

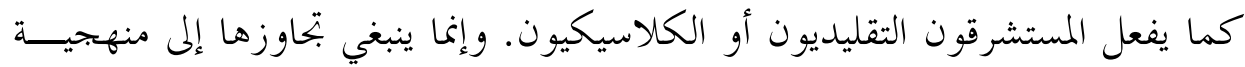

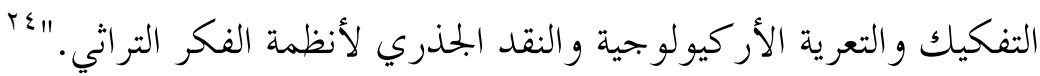
وهذا النص لا يحتاج إلى مزيد بيان، فنقطة الخلاف بينه وبين الاستشراق منهجية لا غير، ويمكننا هنا التمييز بين مستويين من الخلاف، أحدهما مؤاخذته له على أمـــور يتبناها و لم تعد كافية لإعطاء النتائج المتوخاة، و ثانيهما مؤ اخذته على أمور يرفضــــا، مع أها في نظره أقدر على تحقيق الأهداف، و سأعطي بعض الأمثلة على المستويين فيما يلي أولاً: مؤاخذة أركون للمستشرقين على أمور تيبنوها:

وهذه بعض الأمثلة آحذ فيها أركون منهجيّاً على المستشرقين ما يتبنّونه، و نضرب

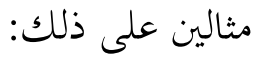


أ. محافظة المستشرقين المعاصرين على المسار المنهجيّ نفسه الــذي ســار عليـهـ

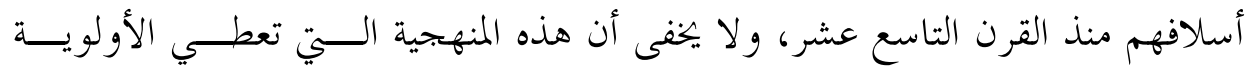

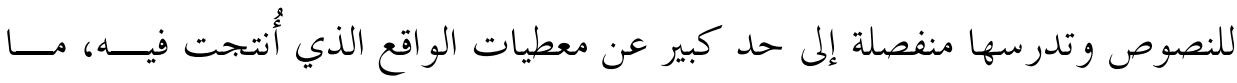

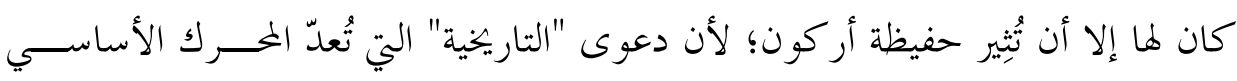

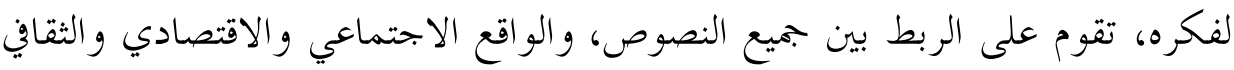

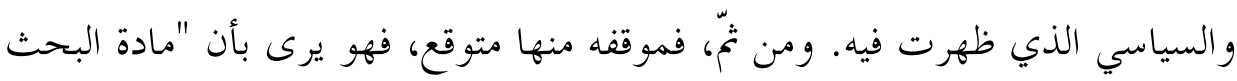

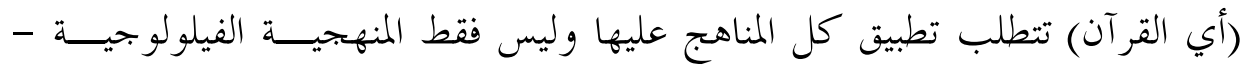

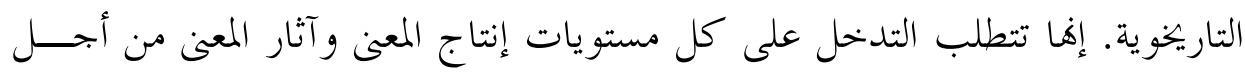

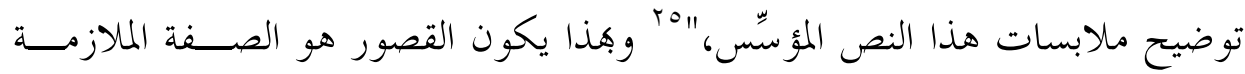

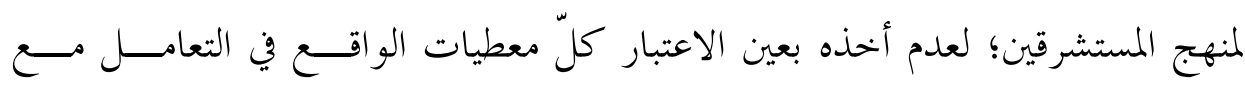

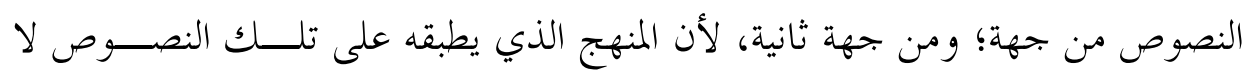

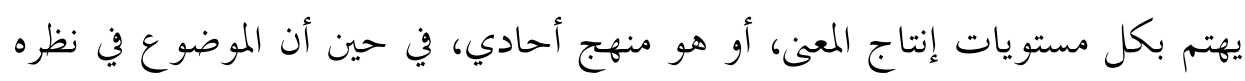
بحاجة إلى مناهج متعددة.

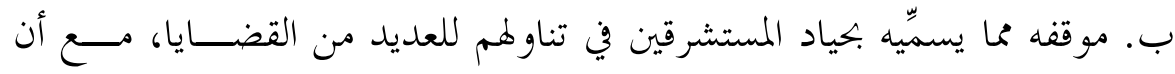

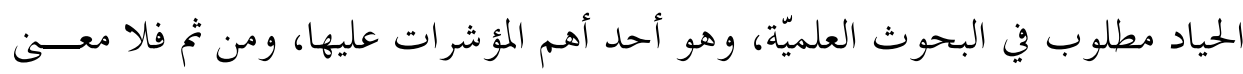

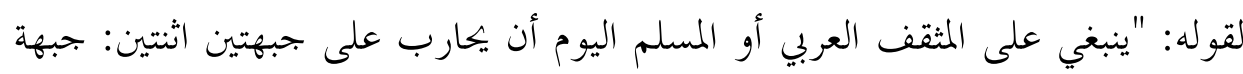

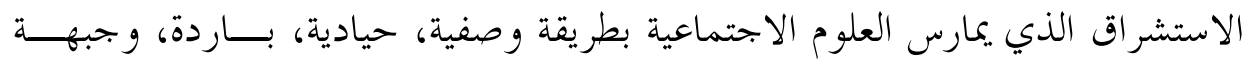

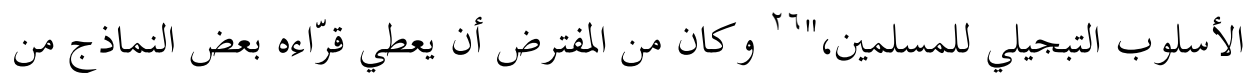

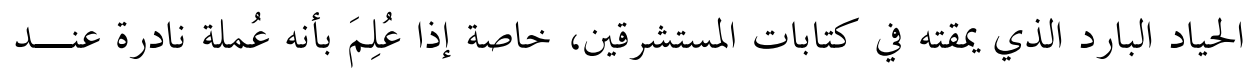
كثير منهم، حسب المعنى الإيجابي للّفظ.

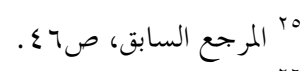

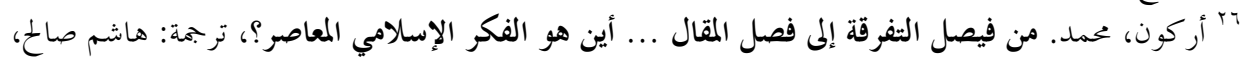


ويبقى الاحتمال الأقرب لمقصود أركون من الحياد، ما يُستخلص بعـــد عمليـــة

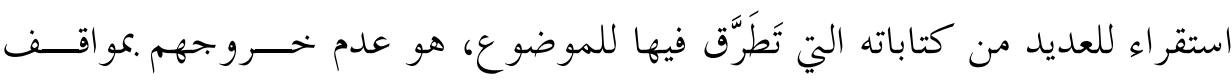

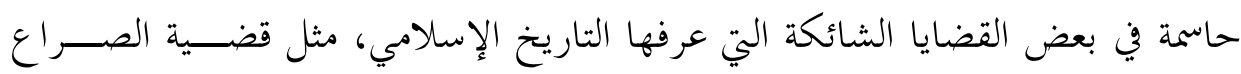

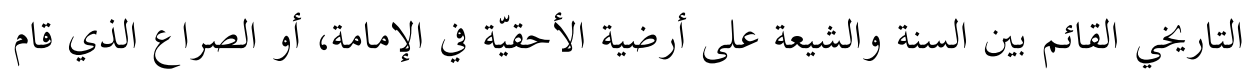

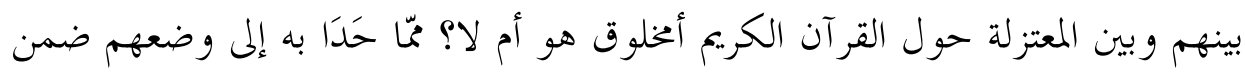

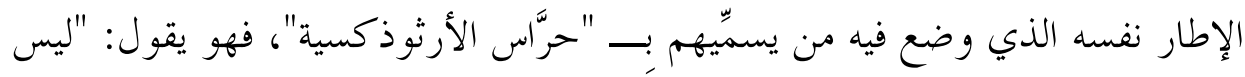

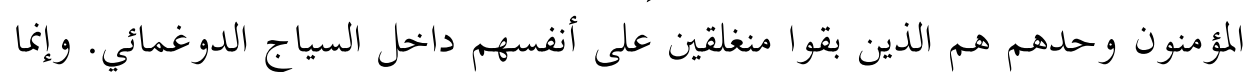

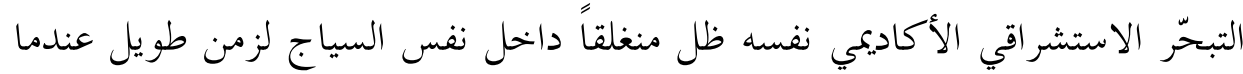
اكتفى بنقل أفكار الإسلام السين الأغلبي إلى اللغات الأوروبية، وذلك قبل أن يفعـــل

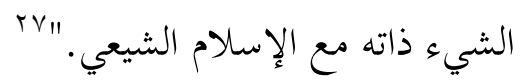

ثانياً: مؤ اخذة أركون للمستشرقين على أمور يرفضوها، مع أها في نظــــره أقــــر

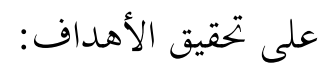

وهذا مستوى آخر له ارتباط بالخلاف في المنهج، يؤسِّسـس أرككـون مشـــروعية

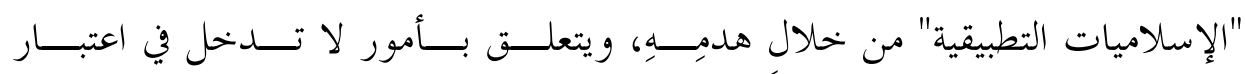
"الإسلاميات التقليدية"، مع أنه -في نظره- كفيل بإحداث ثورة حقيقية في الدراسات

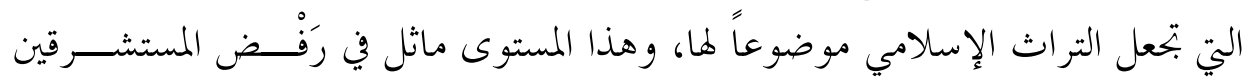

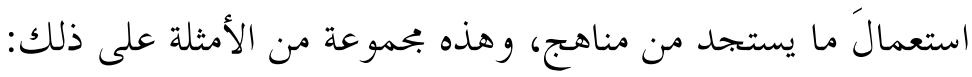

أ. رغم الاستمرارية المنهجية التي تطبع أعمال المستشرقين المعاصرين في علاقتـــهم

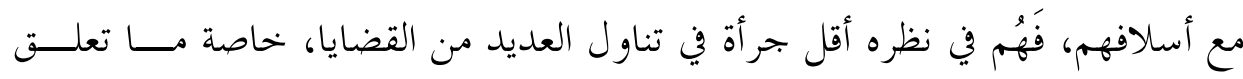

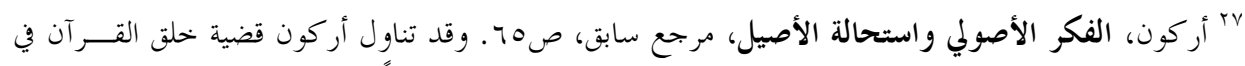

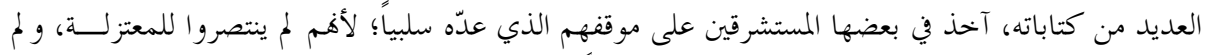

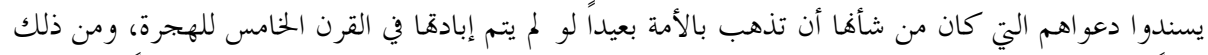

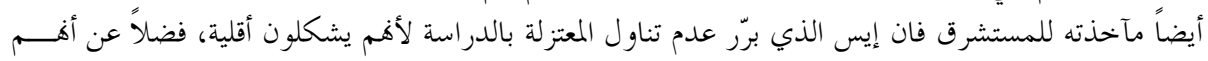


بالدراسات القرآنية، فهو يقول في ذلك: "كانت الأرثوذكسية الإسلامية تضغط دائماً

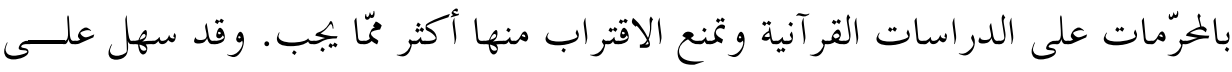
المستشرقين في المرحلة التاريخوية والفيلولوجية أن ينتهكو ا هذه المحرمات أكثر مما يسهل ولهر

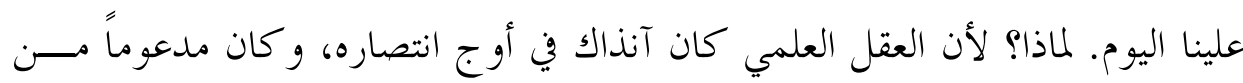

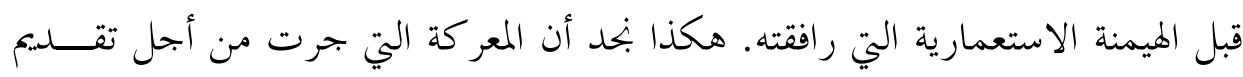

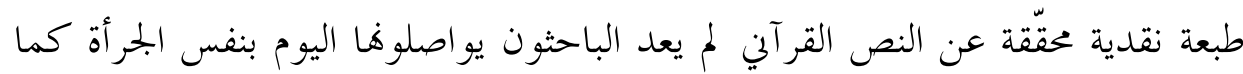

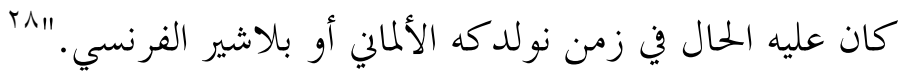
إن هذا النص يمتوي على أفكار عدة يمكن إجمالها فيما يلي: - لقد ادّعى وجود ضغوط من قبل علماء الإسلامجّ على من أراد الخــــوض في

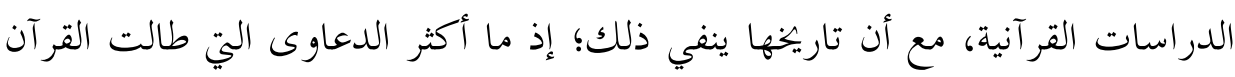

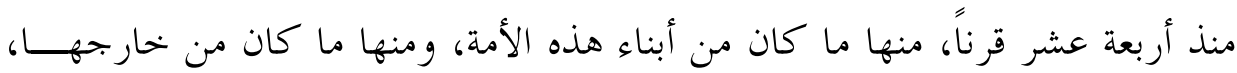

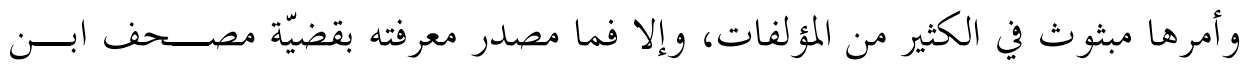

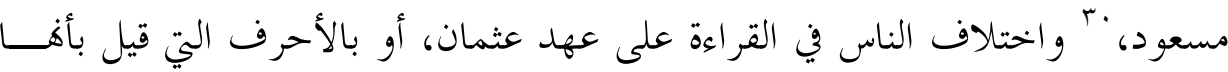

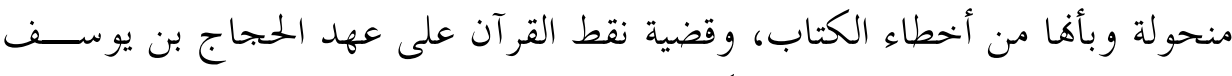
الثقفي، وقراءة ابن شنبوذ التي كثيراً ما لاكتها ألسن المستشرقين، فتتلمذ على شُبهاهم

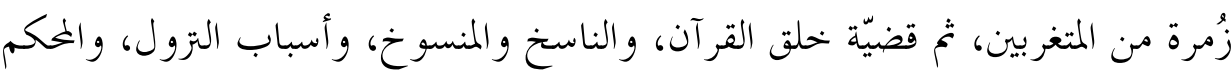

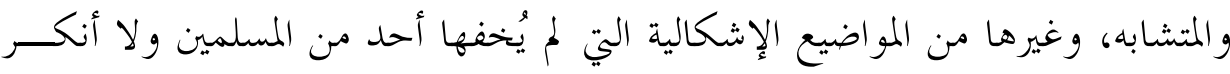

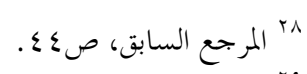

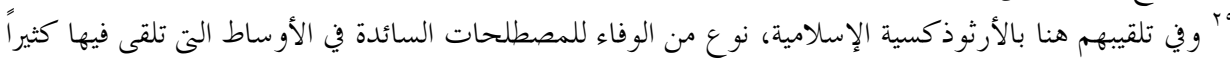

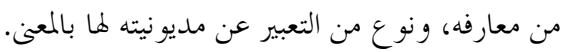

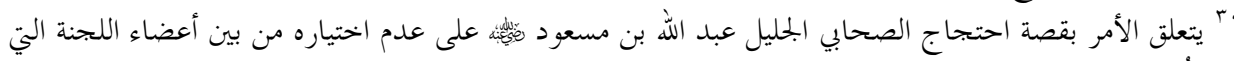

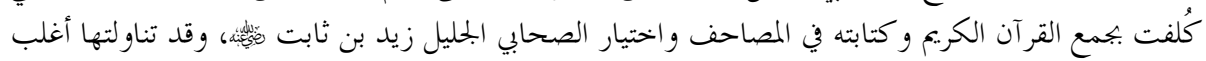

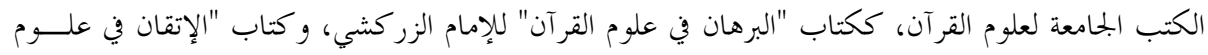

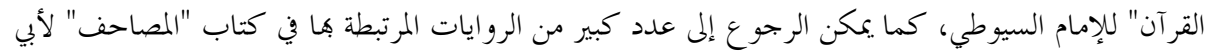

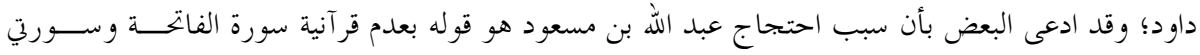

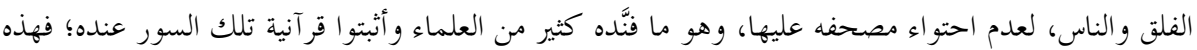

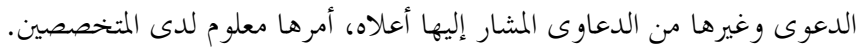


و جودها، بل تناولوها في كتبهم و ناقشوها نقاشاً مستفيضاً، وعن طريقهم وصلت إلينا وإلى كل الذين يُدَنْنِنون حولها.

ــ حديثه عن قدرة المستشرقين في السابق على اقتحام جـــــار التحــــيم بســبـب

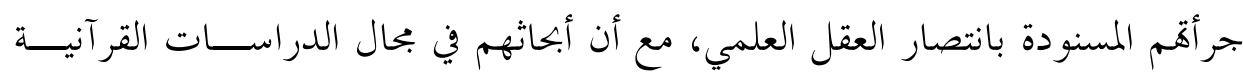
خاصة، كانت بعيدة عن العلمية، فجاؤوا بشبهات؛ بعضها تكرار لما سبق وقيل بــين

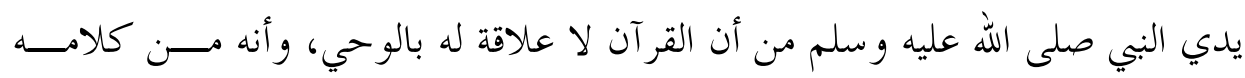

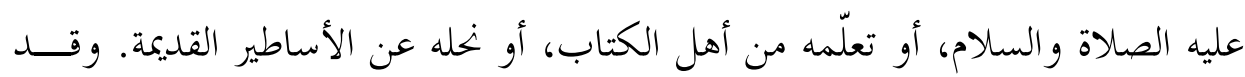

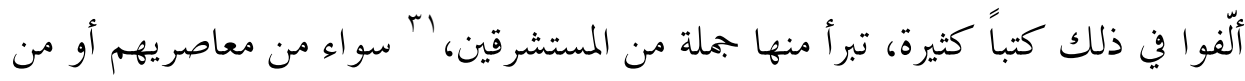

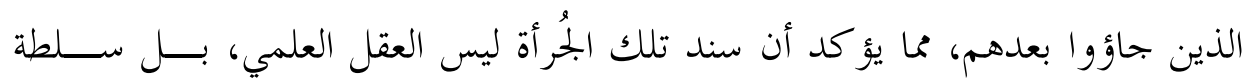

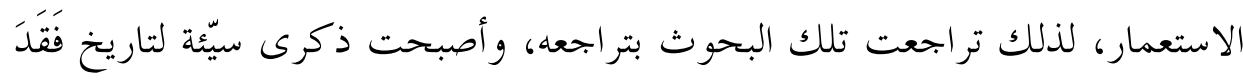

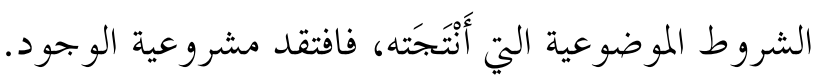
و يزيد قول أركون ضعفاً، عدم تركيز المستشرقين المعاصرين على تلك البحـــوث

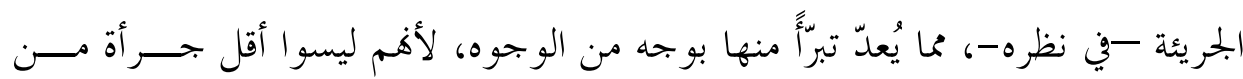

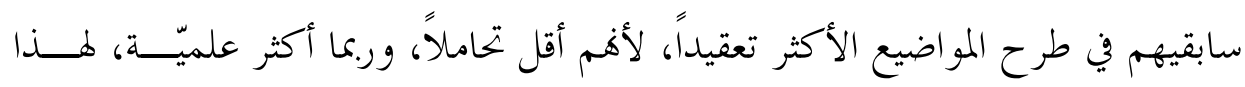

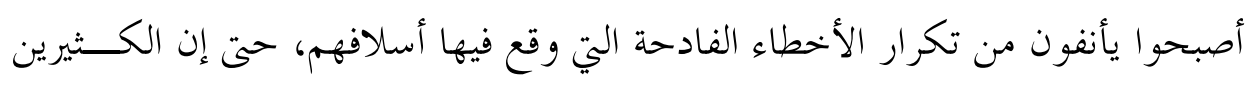

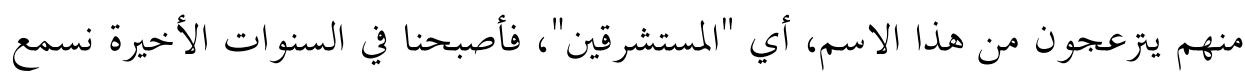
أسماء أخرى، مثل: علماء الإسلاميات أو المستعربين، بَّ وهذا الأمر له دلالته القوية في

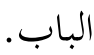

آ أورد عبد الرحمن بدوي في كتابه: "دفاعا عن القر آن ضد منتقديه" عدة أمثلة على على ذلك.

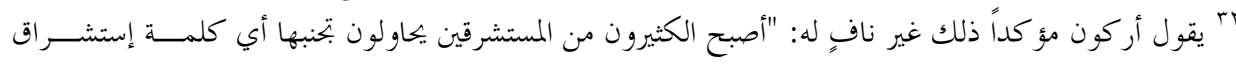

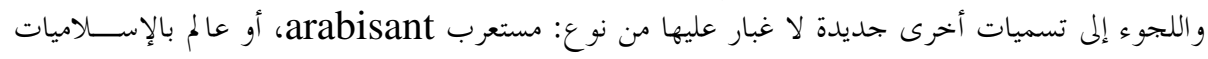
islamologue

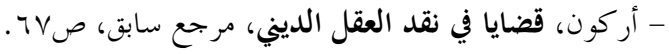


- يرى أركون: "أن المعركة التي جرت من أجل تقديم طبعة نقدية مقققــة عــن

النص القرآي لم يعد الباحثون يو اصلوفا ..."، لنتساءل عن مقصوده من هذا الكلام؟ لئ

ألا يعين هذا الكالام أنه يطعن في صحة متن القـــــآن المتــداول بـــين النـــاس في

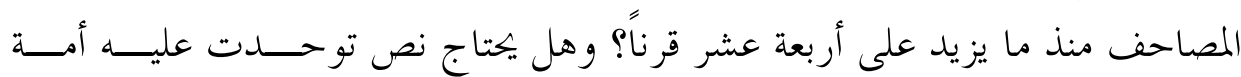
الإسلام عبر قرون عديدة إلى البحث عن نسخة محققة منه؟ خاصة ونُسخه تعدّ بمائات

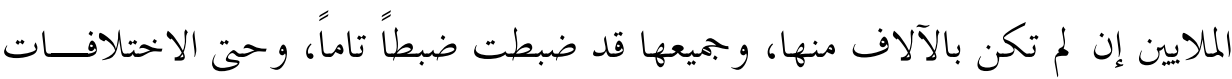
الواردة في الرسم بين رواية حفص عن عاصهم، ورواية ورش عن نــافع، بوصــفهما

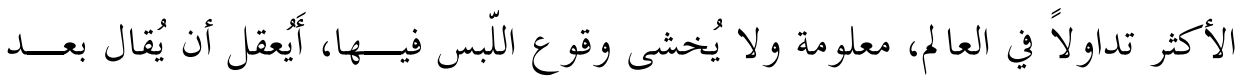

كل هذا بضرورة إيجاد طبعة نقدية محقة؟

إن قول أركون أعلاه، يُظهر ما أضمره في الكثير من كتبه من الطعن والتشكيك

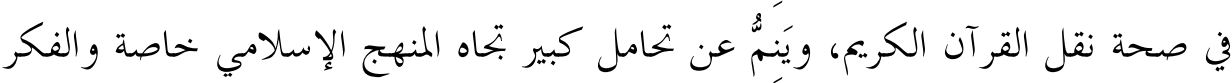
الإسلامي عامة، وإن وجدد له صدى عند أولئك الذين يغيظهم أن يكون للمســـلمين

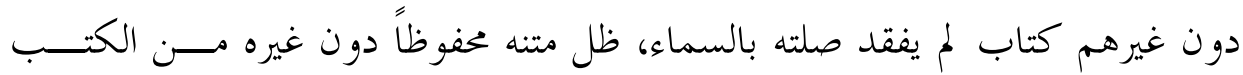

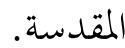

ب. من الانتقادات المنهجية التي وجَّهرا أركون للمستشرقين، قوله: "ولكن العلم الاستشراقي كان يجهل المفاهيم التالية: بنية شبكة العلاقات بين الضمائر أو الأشخاص وته

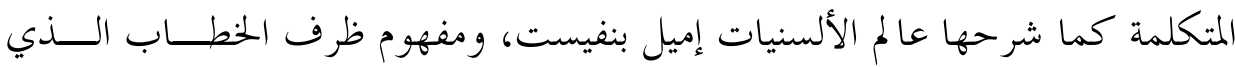
تحدث عنه أو بلوَرَه بِ. زمبتور أثناء دراسته للأدب القروسطي تحت اسم الظـــاهرة الشفهية المقّلّة للظاهرة الكتابية، ومفهوم القوى المهيمنة والقوى المهمّشة الذي يشتمل التهل

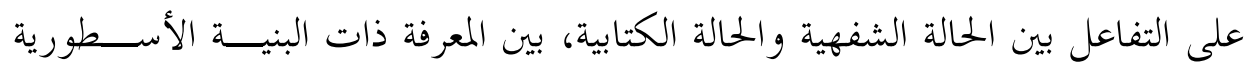
والمعرفة التاريخية النقدية، ثم العصبيات الشغالة والكائنة بين تشكيل الدولة المركزية، ثم الكتابة، و الثقافة الفصحى أو العالِمة. "rr" 
لعله بادٍ للعيان أن أرضية الخلاف منهجية، فمؤاخذته تتعلق بعدم دمج المستشرقين لما استجد من مناهج في علمي الألسنيات و الأنثربولوجيا في بحال اشتغالهم، وتختتلــف

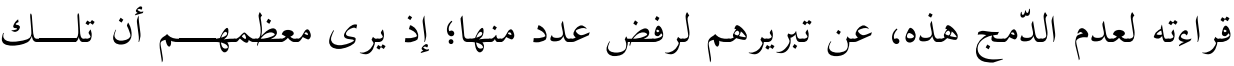

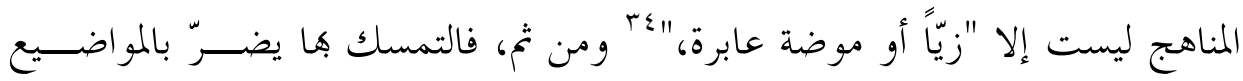
المدروسة أكثر مما ينفعها. أما أركون فيعلُّ ذلك نوعاً من التّملّص من المسؤولية الملقاة على عاتقهم، و السبب الحقيقي في نظره، يرجع إلى كـــوفم "يرفضـــــن أن تســتفيد

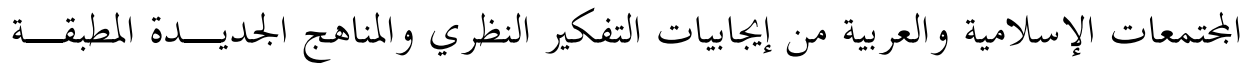

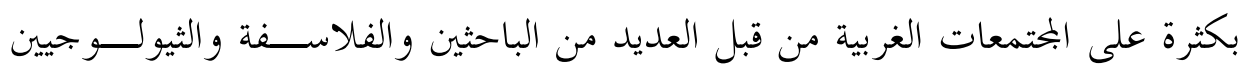
و الكتاب والفنانين." "r وخلفية هذا الموقف -في نظره- ها ارتباط وثيق "بتزعة عرقية مركزية مؤكدة، مفهومة ضمن الوسط التاريخي الذي ولدت فيه. ووحتى الدراســات الجحامعية تسبح في المحيط العام لهذه العرقية المركزية، ذلك أن تفسيراها وتحليلاتها تعكس

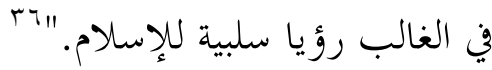

وأيّاً تكن الخلفية الحقيقية الكامنة وراء رفض المستشرقين المعاصرين تَبَبِّي آخــر المكتشفات المنهجية، فالأمر فعلا يقتضي شيئا من التّريث، خاصة وهي لا تزال تلاقي

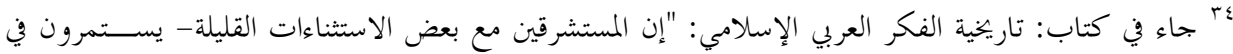

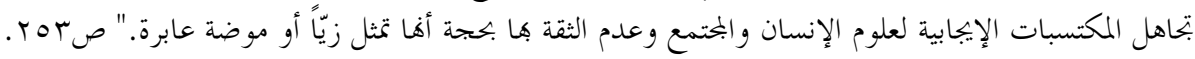
انظر: - أركون، تاريخية الفكر العربي الإسلامي، ترجمة: هاشم صالح، بيروت: مركز الإنماء القومي، الدار البيضاء:

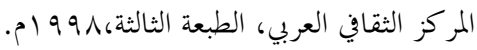

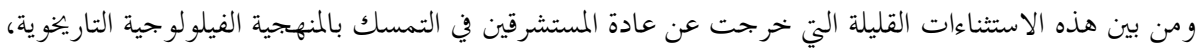

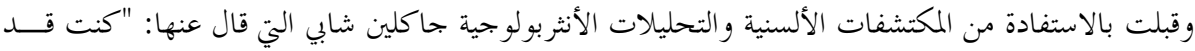

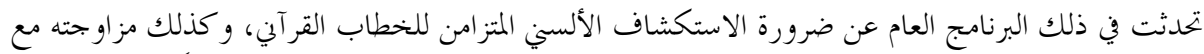

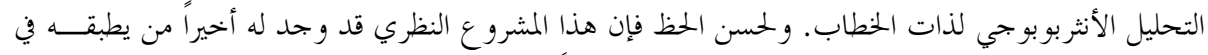

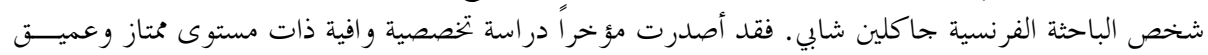

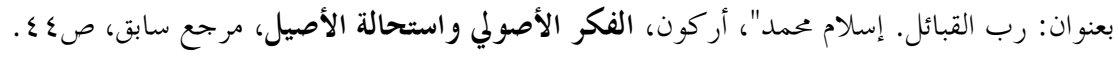

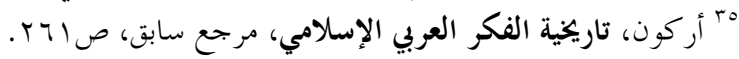

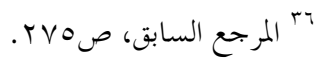




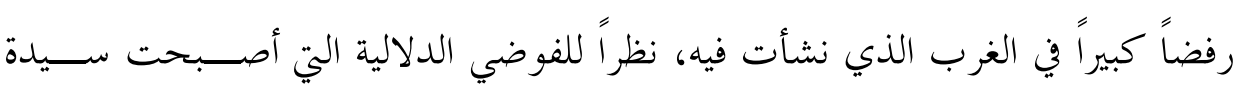

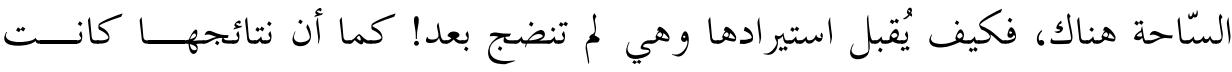
كارثية على النص و المعنى.

ج. هناك نماذج أخرى لها علاقة هذا المستوى، منها قصور منهجية المستشـــقين

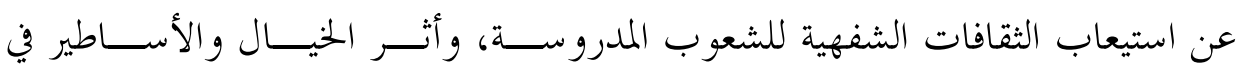

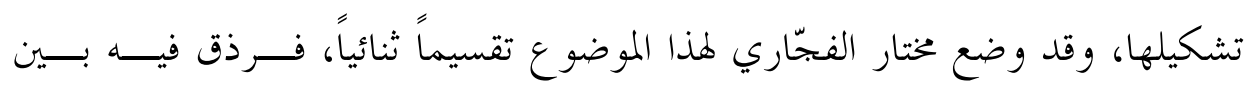

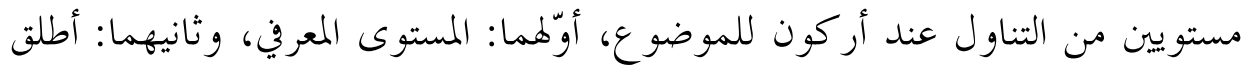

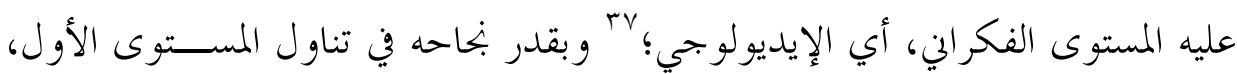

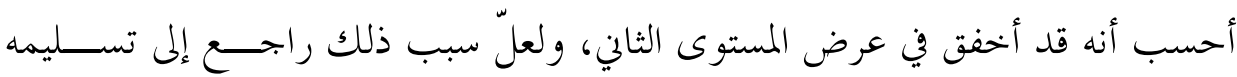

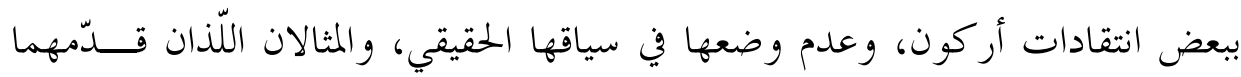

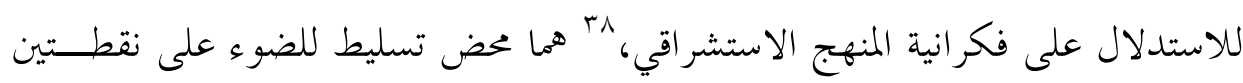

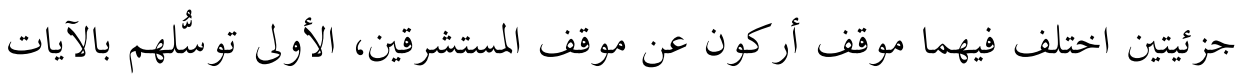

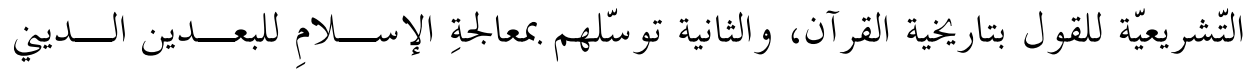

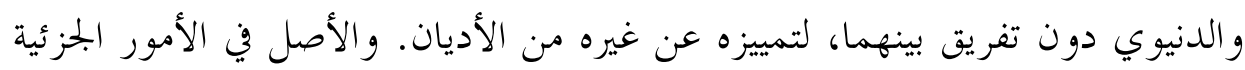

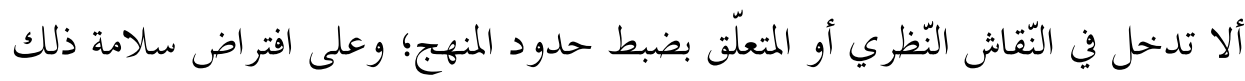

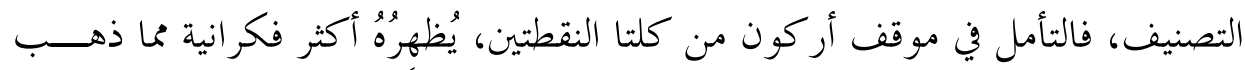
إليه المستشرقون، ودليلنا على ذلك ما يلي:

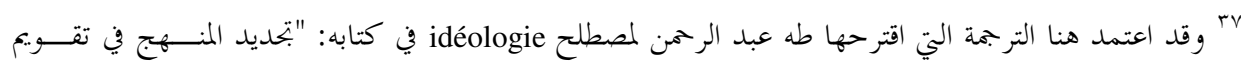

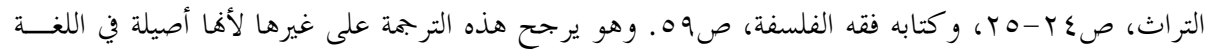

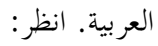

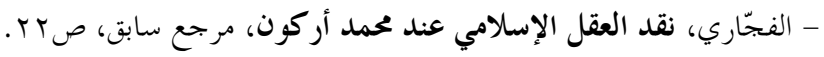

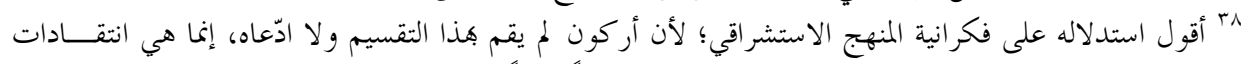

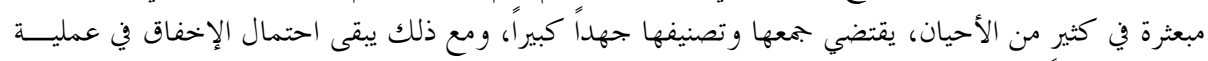
التصنيف وارداً، وهو ما وقع فيه الفجّاري. 
- إن البحث عن أدلة لترسيخ القول بتاريخية القرآن وإقناع الناس به، يُعدّ هَمَّـ مشتر كاً بين أر كون و المستشرقين، و.ما أنّ التوسل بالآيات التشريعية لن يُحقق الهدف

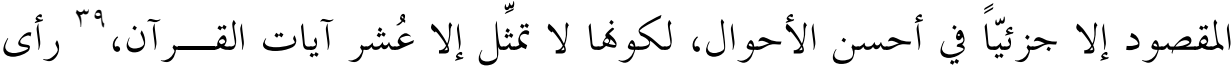

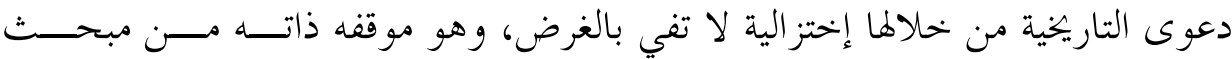
"أسباب التزول"؛ إذ علّه أقرَبَ إلى التّليس منه إلى العلم؛ لأنه هو الآخر لا يستوعب بحمل آي القر آن الكريع، وهو ما يقتضي هافت القول بتاريخيته بناءا عليهما معاً؛ وهذا اختار التوسل بأمور أشمل وأكثر استيعاباً لآي القر آن، مثل: التركيز على لغة الــوحي

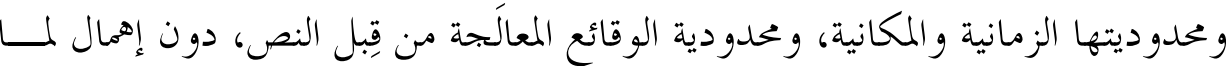
يمكن أن تلعبه الأمور الجزئية الأخرى في الدلالة على التاريخية، مثل: قضـــية أســـباب التزول، و الناسخ و المنسوخ، أو القراءات القرآنية، وغيرها من القضايا الإشكالية. - النقطة الجزئية الثانية اليت أُعطيت للدلالة على فكرانية "الإسلاميات التقليدية"، هي دليل على فكر انية الفكر الناقد لها، و تتعلق -كما سبقت الإشارة إلى ذلك- بعدم فصل الخطاب الإسلامي عموما و القرآني على و جحه اللخصوص، بين الدين و السياسة، أو

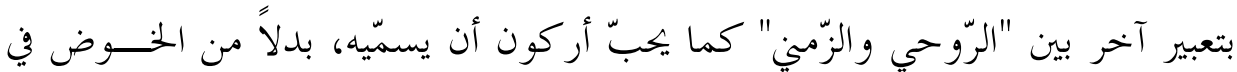

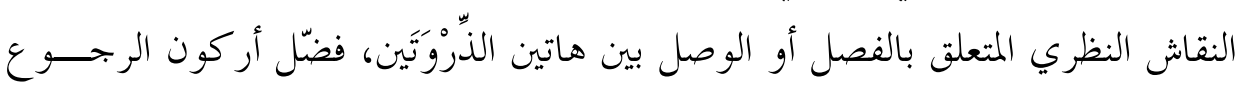

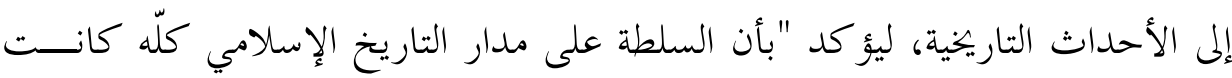
سلطة زمنيّة مضبوطة (أو موجهة) من قبل السيادة الدينية،" "كعنى أن الأصل فيها أكا

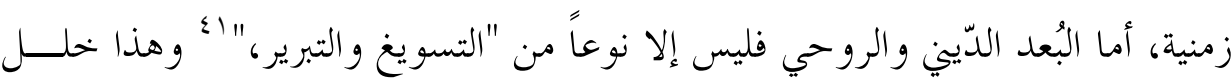

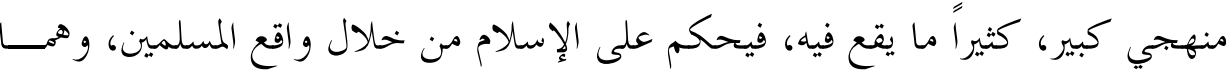

9" قال في هذا الشأن: "الشيء الذي أريد قوله و التشديد عليه هو المعالجة الخاصة التي تعرضت لها الآيات التشريعية،

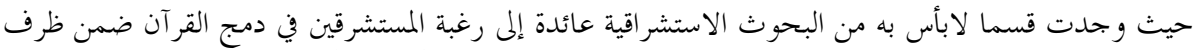

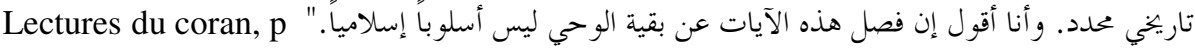

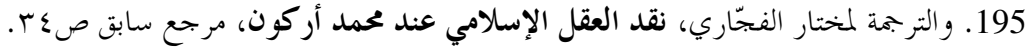

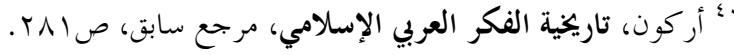

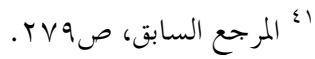


غير متطابقين بالضرورة، ومَن أراد معرفة تصور الإسلام في القضايا السياسية وغيرها، فعليه الرجوع إلى النصوص المؤسِّة له من قر آن و سنة، بَّ لا إلى واقع الناس.

أكتفي هذذه الأمثلة التي أسّس عليها أركون انتقاده بِــــ "الإسلاميات التقليديــة"،

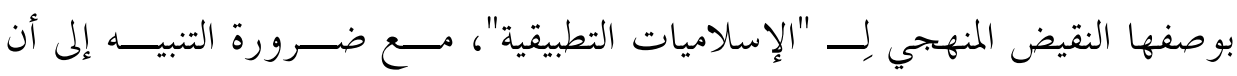
خصائص هذه الأخيرة وحدودها، هي خلاصة انتقاداته للأولى، تلك الانتقادات الــيت يمكن عدّها محاولة بجديدية أكثر جذرية للمسار الاستشراقي على المستوى المنـــهي،

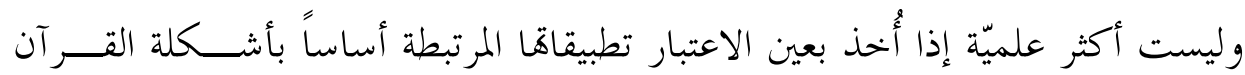
الكريك.

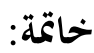

جميل أن كتم بوصفها أمة تصارع من أجل الخروج من أزمة طال أمدها، بما كُّب ويُكتب حول ثقافتنا وحضارتنا و كل تاريخنا، ورائع أن ندقق النظر في الإشارات التي من شأها أن تدفعنا إلى إعادة قراءة الأخطاء والهنات المبثوثة هنا وهناك في تراثنا، لكن الأجمل من ذلك والأروع، أن لا يدفعنا رفضنا لو اقعنا إلى التنكر لماضينا، استلاباً بواقع

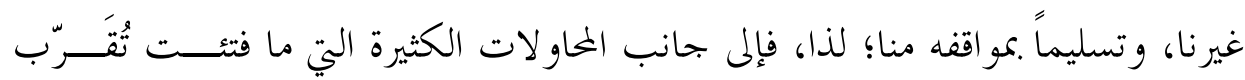

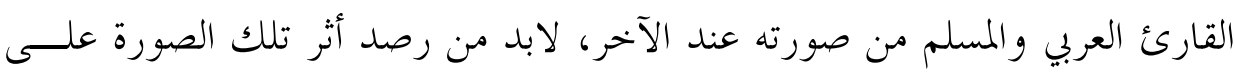

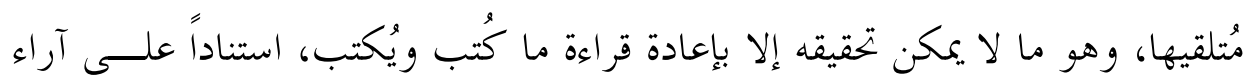
غيرنا في تراثنا. وعمل كهذا، تنوء بحمله العصبة أولو القوة من الباحثين، فكيف تنهض

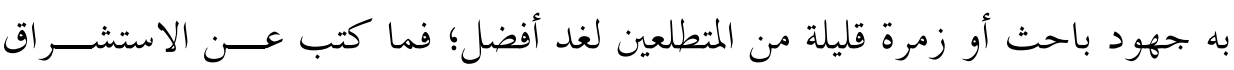

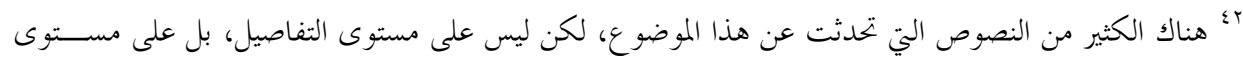

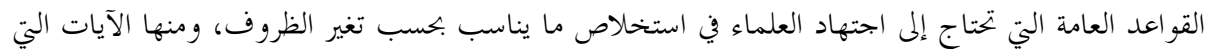

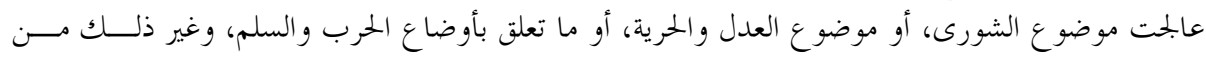

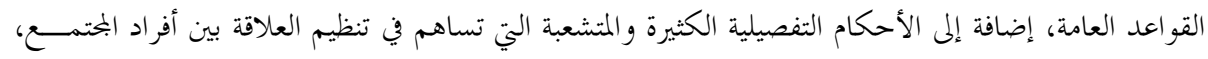

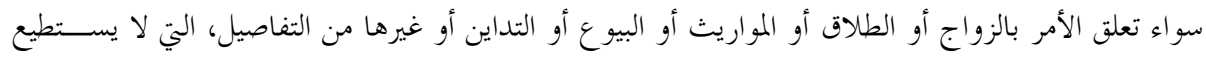


والمستشرقين من دراسات، ليس بالقليل، وفي حقول معرفية متعددة ومتشعبة؛ ولــيس أركون إلا نموذجاً من بين نماذج شتى تغصّ هم السّاحة الفكرية العربية والإسلامية.

حاولنا في هذه الدراسة تسليط الضوء على المستويات الثلاثة التي تحكم علاقتسهـ

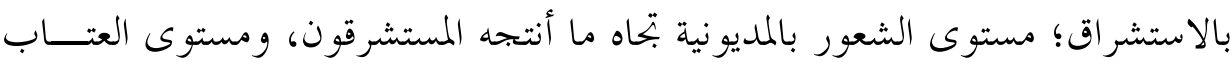

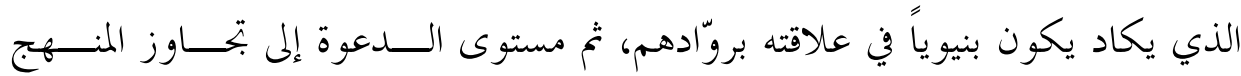

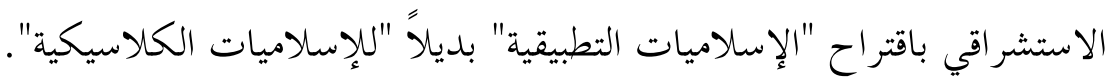

وقد أخضع البحث كل واحد من المستويات الثلاثة إلى الدراسة النقدية، الــيتي لا

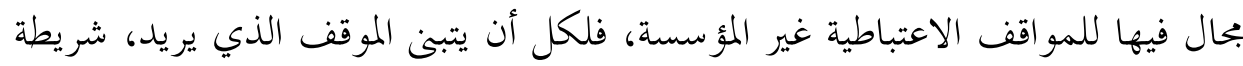

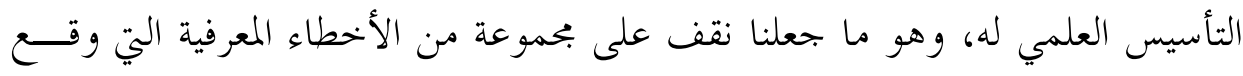

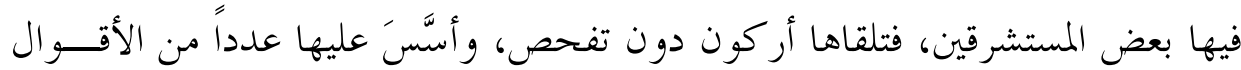

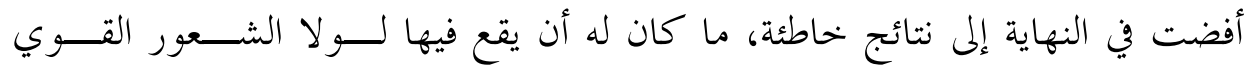

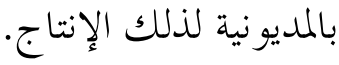

وإذا كان أركون يدعو إلى إعادة قراءة التراث الإسلامي على ضوء ما استجد من

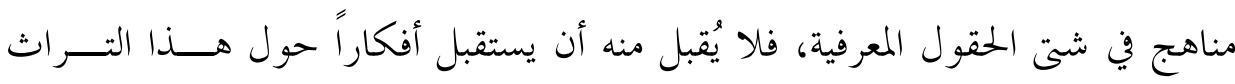

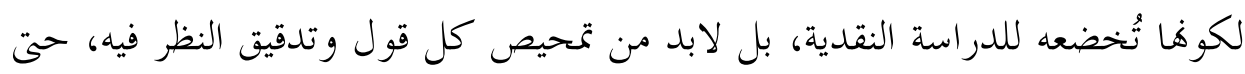

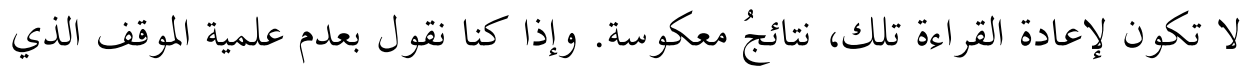

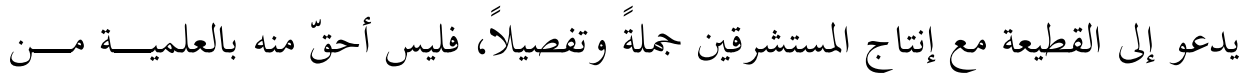

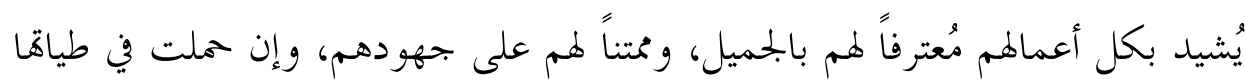

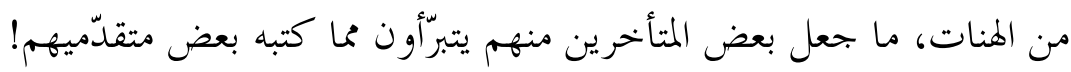
والعلمية تقتضي الكثير من التدقيق والتفصيل، بعيدا عن الشعور بالمديونية الــذي

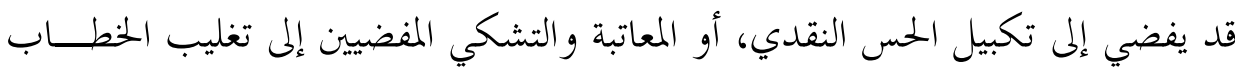
العاطفي على الخطاب العقلاين. 


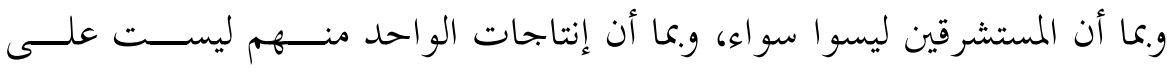

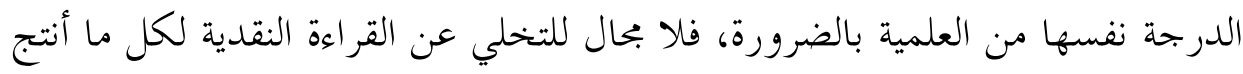

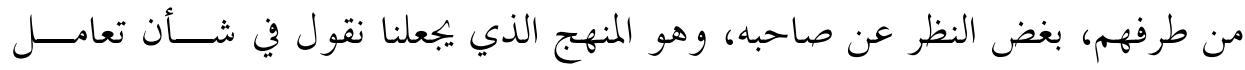

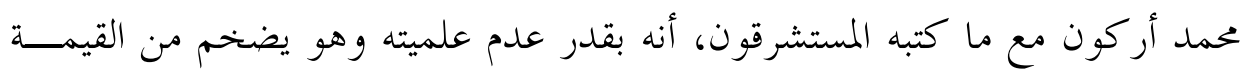

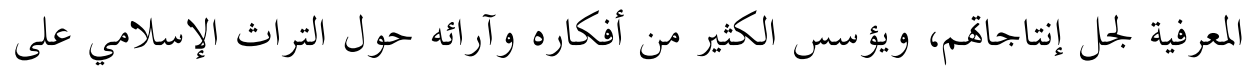

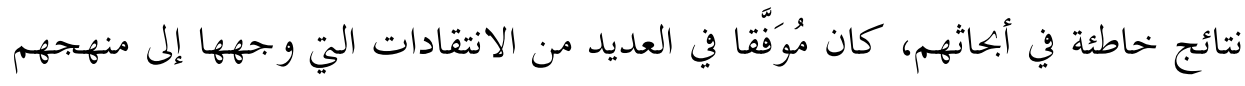

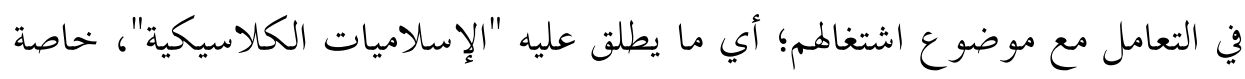

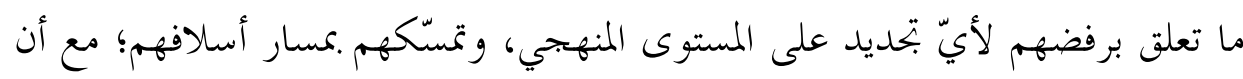

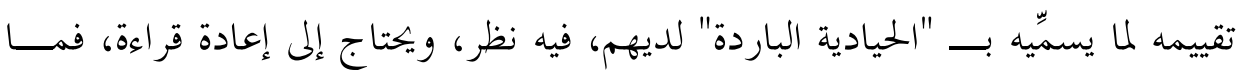

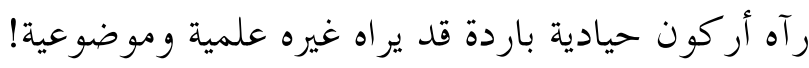

ولا ينبغي أن يُفهم مما سبق، أن دعوته لما يسمى بـــ "الإســاميات التطبيقيـة"

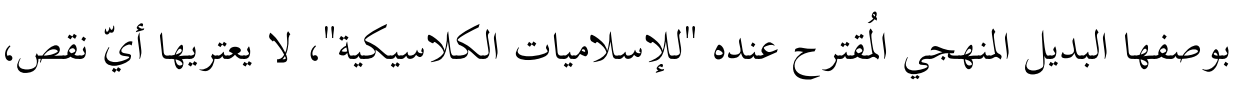

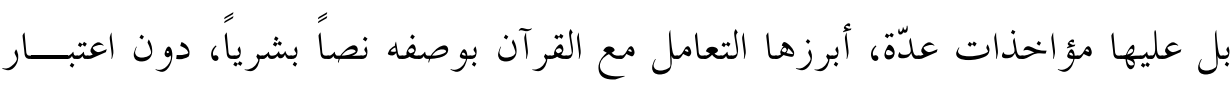

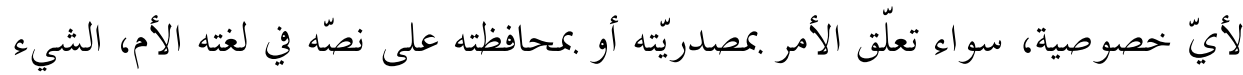

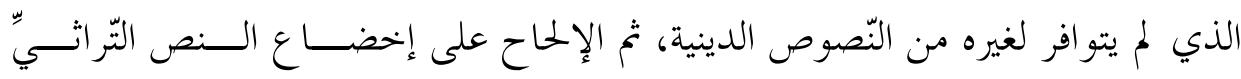

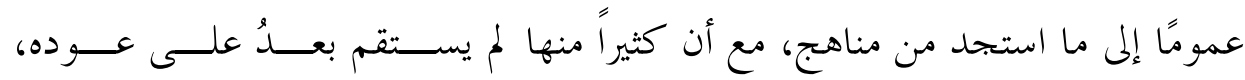

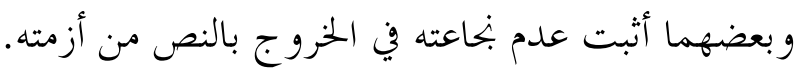

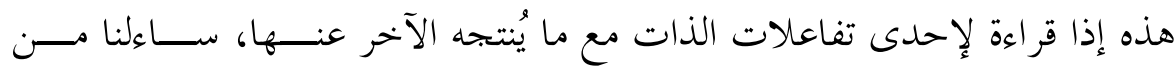

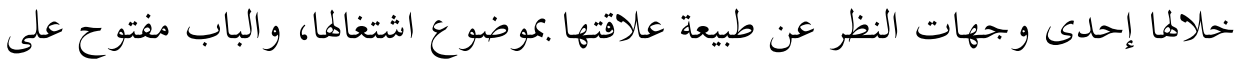

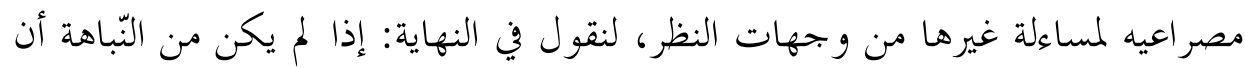

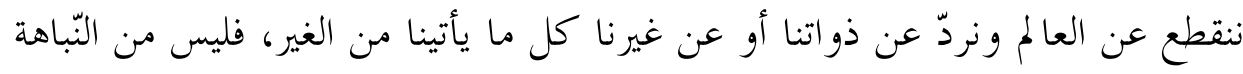

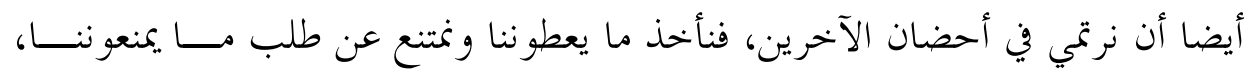
فالحضارة اختيار، و الاختيار مسؤولية، فلنختر ما ينفعنا ولنرفض أن يُختحار لنا. 